\title{
Interaction between Thermal Comfort, Indoor Air Quality and Ventilation Energy Consumption of Educational Buildings: A Comprehensive Review
}

\author{
Lin-Rui Jia ${ }^{1}$, Jie Han ${ }^{1, *}$, Xi Chen ${ }^{2, *} \mathbb{C}$, Qing-Yun $\mathrm{Li}^{3}$, Chi-Chung Lee ${ }^{1}$ and Yat-Hei Fung ${ }^{1}$ \\ 1 School of Science and Technology, Hong Kong Metropolitan University, Hong Kong 999077, China; \\ 17865163055@163.com (L.-R.J.); cclee@hkmu.edu.hk (C.-C.L.); yhfung@hkmu.edu.hk (Y.-H.F.) \\ 2 Department of Mechanical and Automation Engineering, The Chinese University of Hong Kong, \\ Hong Kong 999077, China \\ 3 Teaching and Learning Centre, Lingnan University, Hong Kong 999077, China; rainli@LN.edu.hk \\ * Correspondence: chan@hkmu.edu.hk (J.H.); climber027@gmail.com (X.C.)
}

check for updates

Citation: Jia, L.-R.; Han, J.; Chen, X.; Li, Q.-Y.; Lee, C.-C.; Fung, Y.-H. Interaction between Thermal Comfort, Indoor Air Quality and Ventilation Energy Consumption of Educational Buildings: A Comprehensive Review. Buildings 2021, 11, 591. https://doi.org/ 10.3390/buildings11120591

Academic Editor: Baojie He

Received: 29 October 2021

Accepted: 24 November 2021

Published: 28 November 2021

Publisher's Note: MDPI stays neutral with regard to jurisdictional claims in published maps and institutional affiliations.

Copyright: (c) 2021 by the authors. Licensee MDPI, Basel, Switzerland. This article is an open access article distributed under the terms and conditions of the Creative Commons Attribution (CC BY) license (https:// creativecommons.org/licenses/by/ $4.0 /)$.

\begin{abstract}
Thermal comfort and indoor air quality (IAQ) of educational buildings can affect students' academic performance and well-being and are closely related to ventilation energy consumption. Demands of the indoor environmental quality within the classroom generally vary with the education levels and result in ventilation energy consumption accounting for a considerable proportion of the total energy use in bulk educational buildings. Its huge energy-saving potential is attracting worldwide attention from scholars and governments. Therefore, appropriate operation strategies of ventilation systems should be adopted to effectively reduce energy consumption without sacrificing thermal comfort and IAQ. However, the absence of relevant standards and guidelines for designing a quality classroom environment considering the special features of educational buildings remains an important research question. This study conducts a comprehensive review to determine research gaps and identify future directions for the interaction between thermal comfort, IAQ and ventilation energy consumption for educational buildings. The review results show that: (1) The thermal comfort prediction model should consider the influences of genders, ages and socioeconomic backgrounds; (2) The mixed-mode ventilation coupling the natural and mechanical approaches is preferred given its advantage of lower energy consumption and improved thermal comfort, but its control strategies need further exploration; (3) Optimizing passive design parameters of buildings (e.g., window to wall ratios, window orientations and sun shading installations) can significantly reduce the ventilation demands while maintaining indoor thermal comfort; (4) More studies are required for investigating thermal comfort in educational buildings during the heating period; and (5) IAQ of university buildings clearly requires further studies, especially on bacterial and fungal aerosol pollutants, for a more comprehensive assessment of the built environment.
\end{abstract}

Keywords: thermal comfort; indoor air quality; ventilation energy consumption; educational buildings

\section{Introduction}

The indoor environmental quality (IEQ) performance within the buildings affects occupants' health, emotion, and productivity [1]. 12.6 million deaths were caused by unhealthy environments as estimated by the world health organization (WHO) [2]. Given this severe situation and significance of indoor environmental quality, it arouses worldwide attention from scholars and governments, and much further detailed researches are carried out.

Compared with residential and commercial buildings, educational buildings have a higher population density of 3-4 times [3]. Therefore, the indoor environmental quality in schools becomes more significant because higher $\mathrm{CO}_{2}$ concentrations reduce productivity and limit academic performances, inducing healthy risks to students [4,5]. Moreover, students usually spend 6-8 h on average per weekday in classrooms [6], occupying more 
than $40 \%$ of their daytime [7]. Thus, considering the effects on academic performances and long exposure time, the indoor environmental quality within the educational buildings deserves more attention.

The perceptions of the indoor environmental quality for students are influenced by multiple parameters [8]. The corresponding aspects can be grouped into four categories, including thermal comfort, indoor air quality (IAQ), visual comfort, and acoustic comfort [9]. Among all these mentioned variables, thermal comfort and IAQ are the key factors that significantly affect students' feelings of the indoor environments, followed by acoustic and visual comforts $[5,10]$. Poor thermal comfort and IAQ can lead to increased health-related symptoms, causing absenteeism and loss of concentration [3]. Noticeably, thermal comfort can affect the perception of IAQ to some extent, increasing the tolerance of uncomfortable IAQ for occupants [11,12]. At present, the IAQ is exceptionally crucial for a quality indoor environment, taking the impact of COVID-19 into account [13].

Thermal comfort was defined as "the condition of mind that expresses satisfaction with the thermal environment" in ASHRAE Standard 55. According to the definition by Nicol et al. [14], Comfort or neutral temperature can be reached when the largest number of participants are satisfied [15]. Based on previous studies, thermal comfort affects students academic performances and study efficiency $[16,17]$. The unacceptable thermal conditions caused by excessively high or low temperatures correspond to the distraction and reduction of concentration, slowing down the studying progress [18-20]. By contrast, appropriate thermal conditions are conducive to improving typing and thinking efficiencies by $47.4 \%$ and $32.6 \%$, respectively [20]. Among most studies, the predicting model, including the Predicted Mean Vote (PMV) and Predicted Percentage of Dissatisfied (PPD), is universally applied to evaluate the levels of thermal perceptions of the occupants as a major research focus [21]. PMV ranges from -3 to +3 , and PPD spans from 0 to $100 \%$, while PMV ranging from -0.5 to +0.5 and PPD smaller than $10 \%$ are defined as acceptable conditions for thermal comfort.

As a professional term, indoor air quality (IAQ) is used to characterize indoor air quality [22]. Indoor air pollutions can increase the short-term and long-term disease risks for students and staff in school [23]. Specifically, volatile organic compounds (VOCs) are found to be related to sick building syndrome (SBS) symptoms [24,25]. Carbon dioxide $\left(\mathrm{CO}_{2}\right)$ concentration influences the attendance rate and study efficiency of students [26]. Short-term and long-term exposure to particulate matter (PMs) increases the risk of lung and respiratory diseases [27]. Other indoor air pollutants, such as carbon monoxide (CO), nitrogen dioxide $\left(\mathrm{NO}_{2}\right)$, ozone $\left(\mathrm{O}_{3}\right)$, formaldehyde, etc., may cause acute effects, including skin, eyes, nose, and throat, etc. Hence, all chemical pollutants are worth investigating for possible association with acute impact under short- and long-term exposure, respectively [6]. The indoor air pollution interacts with each site's outdoor sources: urban, rural, industrial, etc. [28-30]. The significant parameters related to the educational environments include the microclimatic parameters (i.e., temperature, relative humidity, and ventilation rate) [31,32], building age [24], occupancy level [33], and floor covering [34] etc. To provide a healthy and comfortable IAQ for students, the governmental, national, and relevant global organizations have developed guidelines and standards for IAQ such as CEN CR 1752, EN 16798-1, ASHRAE 62.1, and ISO/DIS 16814 to guarantee the IAQ.

All the indoor parameters related to thermal comfort and IAQ can be divided into subjective and objective parameters. Subjective parameters (such as metabolic rate and clothing insulation) and objective parameters (such as indoor air temperature, occupants activity level, clothing index, relative humidity, air velocity, and mean radiant temperature) affect occupants' perception of indoor thermal comfort and IAQ and are monitored as the indicators in the evaluation of the indoor environment $[18,20]$. Noticeably, these mentioned factors vary in response to behavioural, physiological, or psychological adaptation [19]. The primary way to record the subjective parameters is to conduct the questionnaire-based survey and thermal sensation votes (TSVs). All participants are asked to complete the questionnaires simultaneously to ensure the constant environmental variables corresponding to 
collected TSVs [18]. Sensors play an essential role in recording the objective parameters, including the indoor and outdoor environmental data. Considering the situation that students spend almost their entire daytime sitting in the classroom, the sensors are installed at a height of 1.0-1.2 $\mathrm{m}$ above the floor near the breathing zone for indoor monitoring $[35,36]$. Moreover, to avoid test errors caused by the outdoor environment, sensors should be placed as close to the room centre as possible, with at least $2 \mathrm{~m}$ away from active heating/cooling systems, doors, and windows [37]. For outdoor monitoring, sensors should be placed at a height of $1.5-2.0 \mathrm{~m}$ above the ground with a minimum distance of $1 \mathrm{~m}$ from the closest building [7].

Both thermal comfort and IAQ are greatly influenced by ventilation because ventilation can remove indoor contaminants and provide the occupants with fresh air, contributing to controlling and improving IAQ [38-40]. In some circumstances, ventilation can be used to adjust the indoor air temperature and relative humidity via the introduced fresh air, resulting in less operation of mechanical systems and corresponding lower energy consumption [37]. It should be noted that heating, ventilation and air-conditioning system (HVAC) accounts for $60-70 \%$ of total energy use in non-industrial buildings, indicating a huge energy saving potential [41]. Providing comfortable thermal conditions and healthy indoor air with lower ventilation energy consumption is therefore desired in the building sector.

Up to now, many relevant review articles have been published, but most of them focus on one or at most two issues among thermal comfort, IAQ, or ventilation energy consumption. For example, Yuan et al. [42] discussed the satisfaction of thermal comfort; Ma et al. [39] analysed the measurement parameters for thermal comfort and IAQ; Sharma et al. [43] studied the indoor thermal performance in naturally ventilated built environments. Only one study concentrates on interactions among these three issues, but not for educational buildings [44]. Therefore, this study aims to fill the current gap by reviewing the interaction between thermal comfort, IAQ and ventilation energy consumption for educational buildings to provide suggestions for future research. To be specific, the objectives for this study include: (1) to clarify the limitations and problems in the evaluation of thermal comfort and IAQ in buildings for different education levels; (2) to review the technologies and control strategies for providing a comfortable indoor thermal environment and acceptable IAQ; (3) to explore the interactions between the thermal comfort, IAQ and ventilation energy; and (4) to present recommendations for saving ventilation energy without sacrificing thermal comfort and IAQ and guide the future works.

Figure 1 depicts the framework of this review study. In Sections 2 and 3, the thermal comfort, IAQ, and their interactions with ventilation strategies considering energy consumption are elaborated. Specifically, in Section 2, the review methodology is illustrated. The basic information of reviewed papers is summarized, such as journals and years of publication, and the research areas. In Section 3, the thermal comfort assessment models are discussed, and the influential factors for thermal perceptions in different educational levels under natural and mechanical ventilation are then discussed with identified research gaps and corresponding recommendations. In Section 4, the school-related IAQ guidelines and the effects of varied IAQ parameters on students' health and academic performance are elaborated. Objectives 1 and 2 are achieved in Sections 3 and 4 . The thermal comfort interacts with IAQ by ventilation, which leads to corresponding energy consumption. Therefore, the relationship between thermal comfort and IAQ, ventilation modes, corresponding energy performance and optimal control strategies are discussed to achieve objectives 3 and 4 . Finally, suggestions for future directions and the limitations of this study are summarized in the last section. 


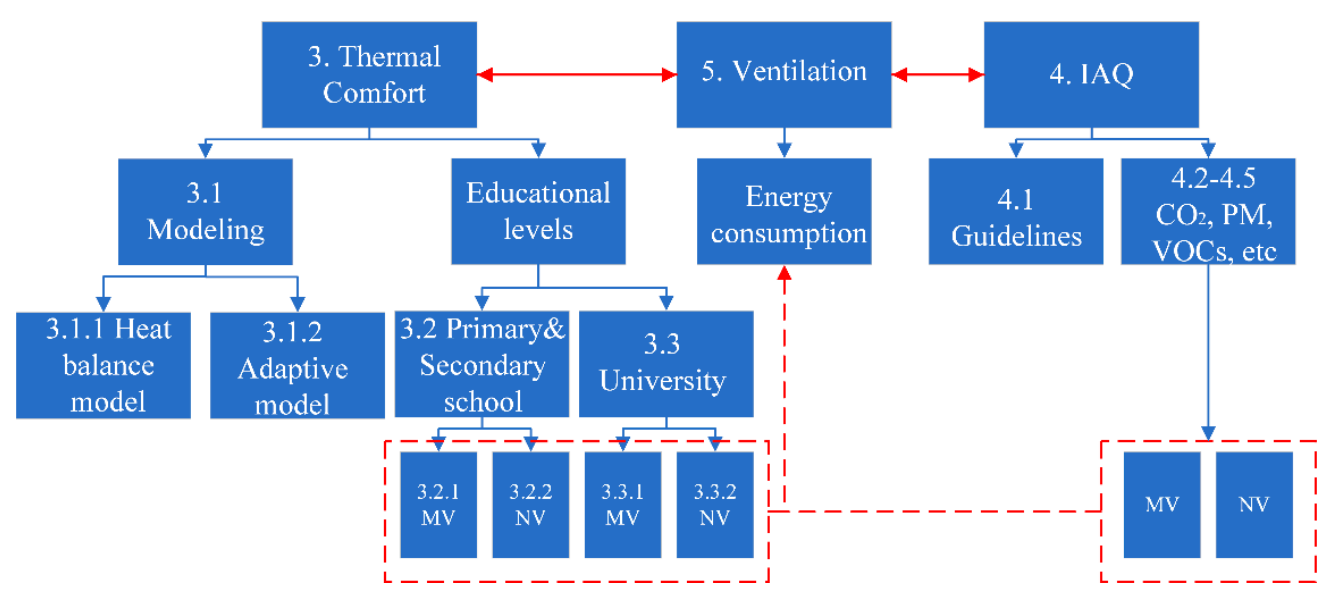

Figure 1. Framework for this review.

\section{Methodology}

The fundamental purpose of this research is to identify and discuss the interactions of thermal comfort, IAQ, and ventilation energy consumption with a focus on educational buildings by critically reviewing previous studies. This section presents the research mythology and brief statistical analysis on the reviewed articles to understand the current research trends. The relationship between thermal comfort, IAQ and ventilation is shown in Figure 2. Overall, these three research aspects affect each other. The ventilation can influence thermal comfort by adjusting the indoor air temperature and relative humidity while impacting the IAQ by controlling the introduced fresh air. Ventilation energy consumption is induced as a result of modulating these two indoor environmental indicators. Moreover, the IAQ also interacts with thermal comfort through varied occupant sensations.

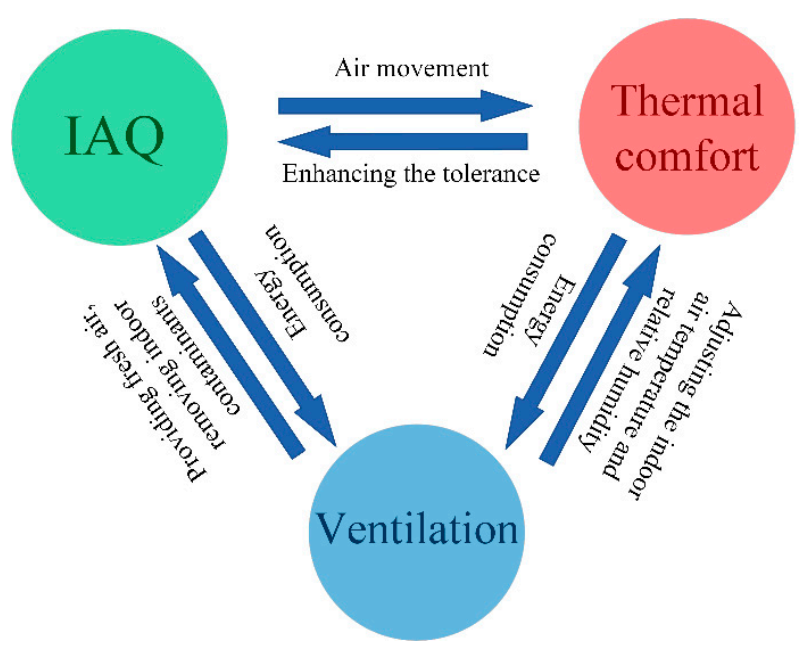

Figure 2. The interactions among the ventilation energy, thermal comfort and IAQ.

The research methodology is shown in Figure 3. Overall, the review is conducted with three steps. First of all, a wide range of literature is generally searched and browsed to narrow down the review topic. Moreover, the related keywords are summarized as inputs for the search engine to identify the topic-specific publications during this process. In the second step, the identified publications are classified according to their detailed research direction. Then, the significant research findings in each classification are discussed for determining review objectives. The comparative analysis points out the current research gaps and provides valuable suggestions for future directions. 
Step one

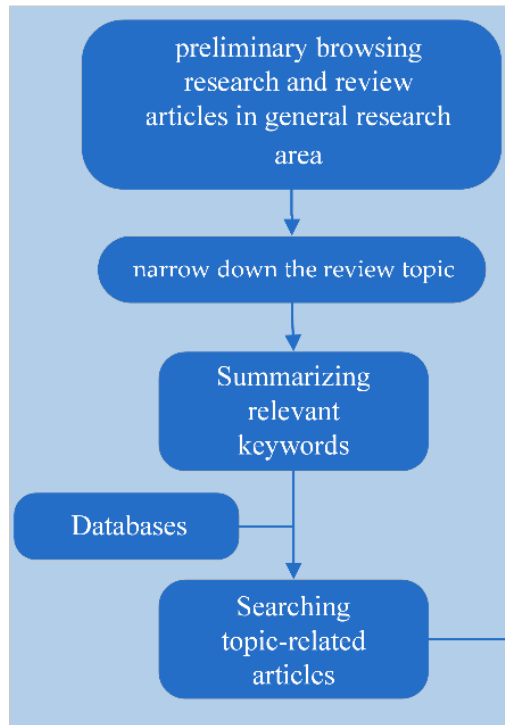

Step two

Reading the

sclected articles

regarding

abstracts and

conclusions
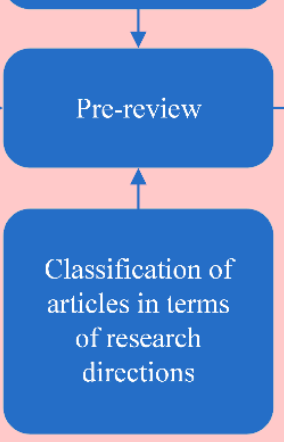

Step three

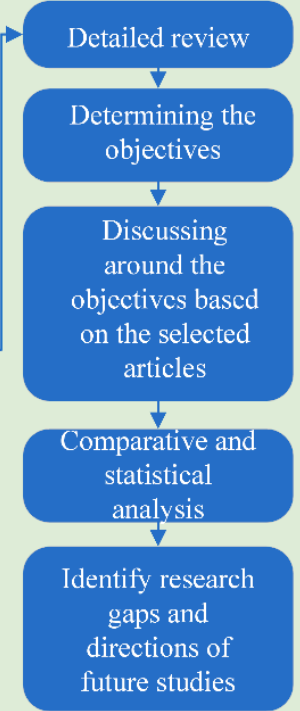

Figure 3. Research methodology.

A bibliometric review was carried out for the articles published in 'Scopus and Web of Science' as proven to be the most credible literature database. Besides, 'Science Direct' and 'Google Scholar' were also adopted for literature search to ensure all related papers were included. Specifically, the combination of below keywords in the titles or the abstracts were used for searching: "educational buildings", "school", "indoor environmental quality", "indoor air quality", "indoor air pollution", "thermal comfort", "thermal condition", "energy consumption", "ventilation", "questionnaire survey". This review can contribute to identifying the current research gap in maintaining and improving the indoor environmental quality in educational buildings, and provide useful recommendations for future studies. As a result, 148 relevant articles were obtained from the search and preliminarily classified based on the publication year, journal and country for further discussions. The scope of this review is demonstrated in Figure 4.

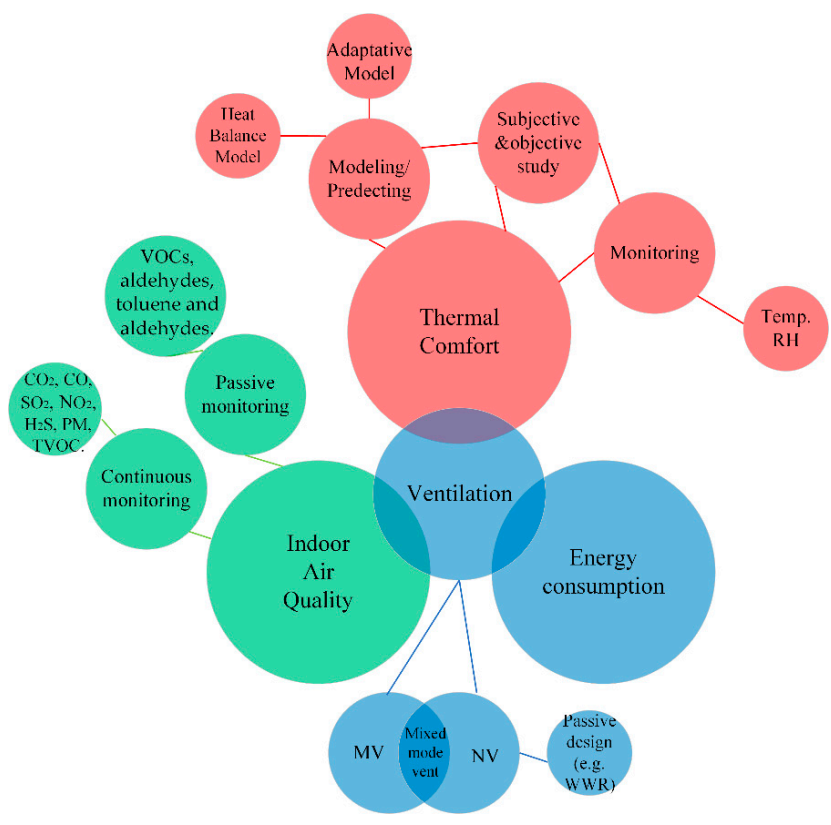

Figure 4. Scope of review for this manuscript. 


\subsection{Year of Publication}

Firstly, the reviewed articles are classified by the publication year to learn the research trend in indoor environmental quality fields. Figure 5 demonstrates a boom of relevant research since the year of 2000, where searched articles rapidly increase from 2 in 2000 to 18 in 2021. Generally, it can be concluded that people have started paying more attention to indoor environmental quality with increasing demands of health and wellness due to the rapid development in the economy and society.

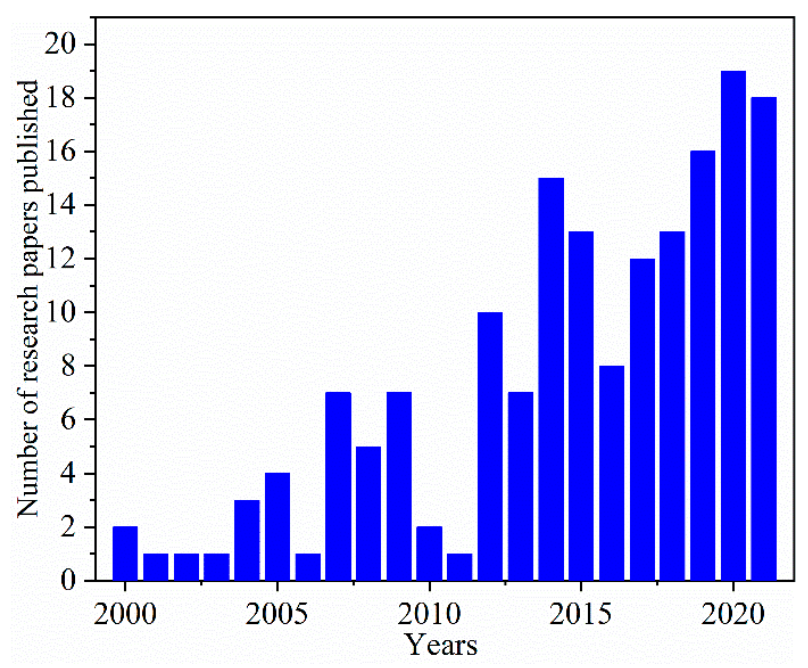

Figure 5. The number of published papers related to thermal comfort, IAQ and ventilation over the years.

\subsection{Country and Region of Publication}

The development of one country's GDP and the number of IEQ-related papers published can reflect peoples' concerns and requirements for indoor environmental quality. Therefore, the published articles are summarized and classified by the authors' research areas with an indication of the corresponding countries' GDP, as shown in Figure 6. This figure demonstrates that the authors coming from China published the most articles (i.e., 24) for IEQ focused on educational buildings, followed by the UK, Italy, Spain, and India, where corresponding numbers of articles are 14,13, 9 and 7, respectively.

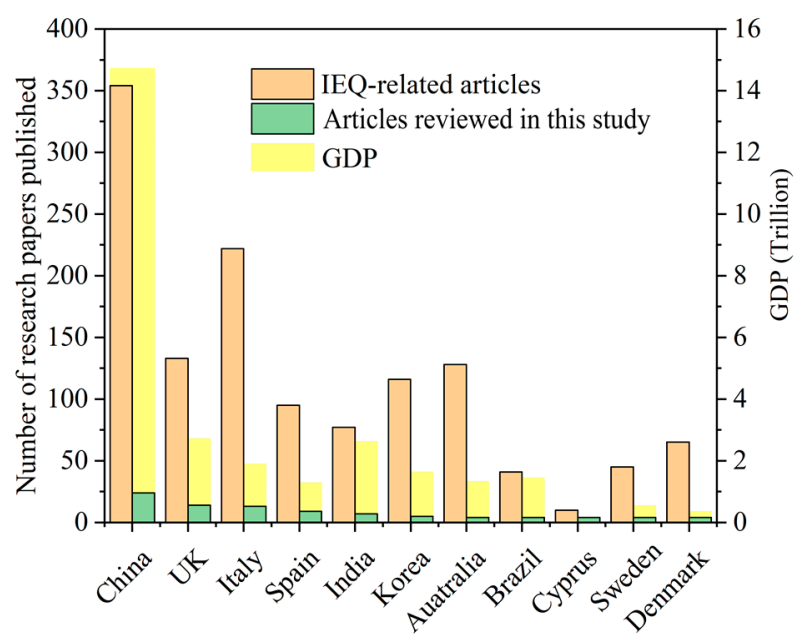

Figure 6. Number of related papers published in different countries. 


\subsection{Journal of Publication}

The top-10 related journals are summarized and ranked by the number of published papers shown in Table 1. It can be noticed that 'Building and Environment' ranks the first with 46 relevant articles published, followed by the 'Energy and Buildings' with 24 articles, 'Indoor Air' with 7 articles, 'Applied Energy' with 6 articles, etc. For the remaining journals, some relevant articles were also published, while the total number of their papers is still less than the first journal. In general, 'environment' and 'energy'- related journals are the main sources of relevant articles given their close correlation with the theme of this study, which can further reflect society's concern for the indoor environmental quality in educational buildings.

Table 1. Classification of published articles by journal categories.

\begin{tabular}{ccc}
\hline NO. & Journal Name & Number of Published Papers \\
\hline 1 & Building and Environment & 46 \\
2 & Energy and buildings & 24 \\
3 & Indoor Air & 7 \\
4 & Applied Energy & 6 \\
5 & Atmospheric Pollution Research & 6 \\
6 & Science of the Total Environment & 6 \\
7 & Atmospheric Environment & 4 \\
8 & Journal of Building Engineering & 4 \\
9 & Energy & 3 \\
10 & Journal of Environmental Management & 3 \\
\hline
\end{tabular}

\section{The Studies on Thermal Comfort}

\subsection{Thermal Comfort Assessment Model}

Research of thermal comfort is absolutely a composite field, depending heavily on indoor set-point temperature, occupancy and heat recovery rate, etc. [45]. To better understand the interactions between influential factors and optimize the thermal environment, the predicting model plays a greatly important role, and two main methods to evaluate thermal comfort are used worldwide, including the Fanger's heat balance model and the adaptive model [46]. According to Fanger's heat balance model, the occupants are just passive recipients of the indoor thermal environment, which has been challenged by an adaptive model that occupant can adjust their behaviors to adapt to the indoor environment. In this section, the two models will be elaborated respectively. The thermal comfort models commonly used are demonstrated in Table 2.

Table 2. Thermal comfort assessment model [39].

\begin{tabular}{|c|c|c|}
\hline Model Type & Analytical Model & Limitation \\
\hline Heat balance model & $\begin{array}{l}\mathrm{PMV}=f\left(M, W, f_{\mathrm{cl}}, p_{\mathrm{a}}, T_{\mathrm{db}}, T_{\mathrm{cl}}, h_{\mathrm{c}}\right) \\
M=\text { the metabolic rate, } \mathrm{W} / \mathrm{m}^{2} ; W=\text { effective mechanical } \\
\text { work } / \text { power, } \mathrm{W} / \mathrm{m}^{2} ; f_{\mathrm{cl}}=\text { the ratio of clothing surface area to } \\
\text { the exposed surface area; } p_{\mathrm{a}}=\text { vapor pressure of water; } \\
T_{\mathrm{cl}}=\text { the clothing surface temperature, },{ }^{\circ} \mathrm{C} ; T_{\mathrm{db}}=\text { dry bulb } \\
\text { temperature, },{ }^{\circ} \mathrm{C} ; h_{\mathrm{c}}=\text { the heat exchange by evaporation on the } \\
\text { skin, }{ }^{\circ} \mathrm{C} \text {. }\end{array}$ & steady-state \\
\hline Adaptive model & $\mathrm{aPMV}=\left(\mathrm{PMV}^{-1}+\beta\right)^{-1}$ & \\
\hline Adaptive model & $\begin{array}{l}\beta=\text { adaptive coefficient. } \\
\text { nPMV }=\gamma \cdot 4.03+0.0949 \cdot \text { Top }+0.00584 \cdot R H \%+1.201 \cdot M \cdot \\
f_{\mathrm{cl}}+0.000838 \cdot T_{\text {out }}^{2} \\
T_{\mathrm{op}}=\text { operation temperature; } R H \%=\text { relative humidity; } \\
\mathrm{M}=\text { metabolic rate, } f_{\mathrm{cl}}=\text { the ratio of clothing surface area to the } \\
\text { exposed surface area; } T_{\text {out }} \text { and the outdoor mean air } \\
\text { temperature. }\end{array}$ & $\begin{array}{l}\text { Cause inaccurate estimation of } \\
\text { thermal comfort due to the } \\
\text { unsuitable estimation on } \\
\text { occupants' clothing insulation } \\
\text { and metabolic rate }\end{array}$ \\
\hline
\end{tabular}




\subsubsection{Heat Balance Model}

The heat balance model simplifies the thermal perception as a function of the occupant bodies' thermal balance [47-49]. Applying the heat balance model needs four measured physical variables as inputs, including the air temperature, airspeed, relative humidity, and globe temperature. Besides, two personal estimation parameters are also required, including the metabolic rate and clothing insulation [47-49]. The widely used PMV-PPD model is based on this heat balance model. However, this model ignores the characters of the buildings and the influence of climates, which significantly influence the acceptable zone of thermal perception and cause considerable evaluation relative errors [49-52]. It was pointed out that this model cannot be used in the evaluation of the dynamic quality of the indoor environments with the uncertainty can reach up to \pm 0.5 [49]. In order to improve the predicting accuracy of the heat balance model, using additional correction factors as a significant solution to reduce the model predicting uncertainty are suggested $[21,53]$. Moreover, as reported, providing reasonable clothing insulation and metabolic assessment as model inputs can also contribute to accurate indoor thermal comfort evaluation [54].

\subsubsection{Adaptive Model}

The adaptive model allows the occupant to adjust their behaviours to adapt to the indoor environment. Taking adaptative behaviours is conducive to improving the perceptions of thermal comfort [55]. Based on the adaptive comfort theory and the model assumptions, the occupants are treated as an active controller in creating an 'ideal' indoor thermal environment by adopting personal behaviours or adjusting the surrounding environments [56]. Moreover, the comfort zone becomes wider with more available adaptive opportunities [57]. Principal adaptive opportunities available to students include clothing level change, opening windows, regulating ceiling fans, etc. [52]. The adaptive approach is commonly used in naturally ventilated buildings [58].

In conclusion, the heat balance model is partially restrained by the model assumptions, whilst the adaptive model can take occupants' subjective will into account. Therefore, in comparison to the heat balance model, the adaptive model, as expected, can provide more accurate predictions for indoor thermal feelings. However, similar to the heat balance model, evaluation errors are inevitable for adaptive models. The following sections will discuss the drawbacks of these two models applied in the actual application cases with different education stages.

\subsection{Thermal Comfort in Primary School and Secondary School}

Primary and Secondary schools' classrooms are usually occupied by students of ages between 6-18 approximately. Assuming that the thermal perceptions of children are similar to those of adults could cause considerable inaccuracy in indoor thermal evaluation [59]. A better understanding of the children's thermal perceptions and the corresponding impacting factors becomes crucial for improving their academic performance and health development. Hence, in this section, the thermal performances of children were analyzed respectively for naturally ventilated classrooms and mechanical ventilated classrooms. And the types of the mechanical ventilation system are discussed in reference [60] and illustrated in Figure 7. The references reviewed in this section have been summarized in Table 3, presenting the characteristics of the education levels, ventilation operation modes, age groups, etc. 


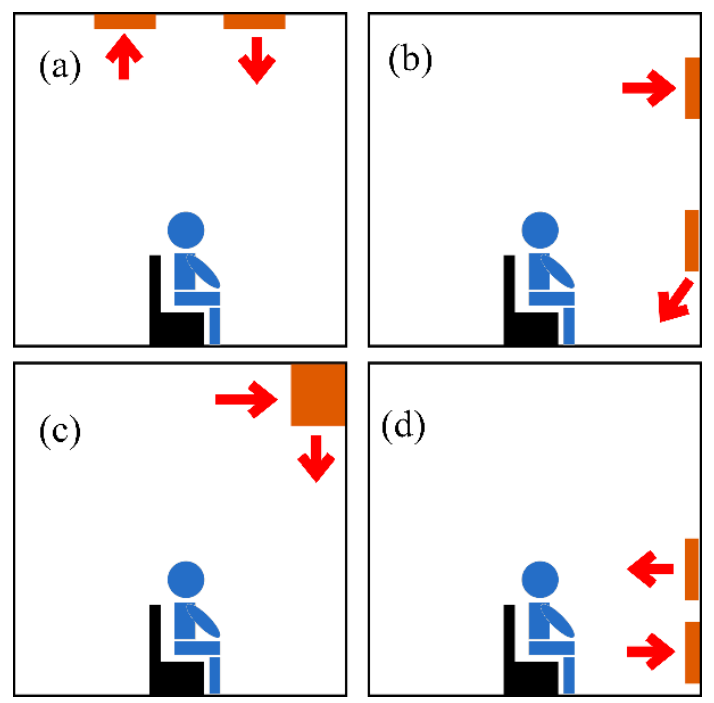

Figure 7. Typical mechanical ventilation types. (a) Mixing ventilation. (b) Impinging jet ventilation. (c) Wall confluent jets ventilation. (d) Stratum ventilation.

\subsubsection{Natural Ventilation (NV)}

Natural ventilation (NV), as one of the fundamental strategies in the energy-efficient design of buildings, operates with airflows driven by gravity forces, without electricity consumption [61]. Classrooms with NV are prevalent in most countries due to their simplest operation and lower initial investment. In cold regions, NV is operated in the spring and autumn, whilst it can be used throughout the year in tropical areas.

The PMV-PPD model is universally adopted to assess the interior thermal comfort across different areas of the world. However, the adult-based thermal evaluation model is not appropriate for assessing the thermal perceptions of children studying in primary and secondary schools, as indicated by some preliminary studies. For example, Mors et al. [19] verified that the PMV model could not predict the thermal sensation of these children accurately, underestimating the mean thermal sensation up to 1.5 scale points. AparicioRuiz et al. [50] also observed a discrepancy between the PMV predictions and the thermal sensation votes (TSVs), concluding that using PMV will cause maximum predicting errors for children exposed to heating environments for a long time. These produced relative errors can be attributed to the fact that children prefer lower temperatures than adults to feel comfortable $[62,63]$. Therefore, the temperature in classrooms should be kept a few degrees lower than that in the office where the teachers work inside [64,65]. To improve the prediction accuracy of the PMV-PPD and adaptive models, some adjustments are suggested, such as calibrating PMV models by addressing the difference in metabolic rates and correcting the input metabolic value by accounting for the smaller body surface area of children [66-68].

Adaptive behaviours can impact the thermal perceptions of the occupants. Students in naturally ventilated classrooms are likely to practice adaptive methods such as opening windows or blinds and clothing adjustment. However, Corgnati et al. [69] pointed out that children have limited adaptivity opportunities. Excluding the change of clothing layers, they might not be capable of opening or closing windows or changing their activity level to adapt to specific environments according to their personal will. Giuli et al. [70] concluded that the classroom indoor environments largely depend on the teacher's personal thermal preferences, which may differ from the preferred thermal conditions of children. Thus, Korsavi et al. [71] suggested that school managers should encourage children to practice personal adaptive behaviours to reach thermal comfort after a TSVs survey conducted in 32 naturally-ventilated classrooms. The adaptive model is similar to the heat balance model that can cause relative errors between the predicting results and real TSVs. Trebilcock et al. [72] found that the comfort temperature obtained from TSVs is 
significantly lower than those predicted by the adaptive comfort model established mainly for adults.

In addition to the classroom's external physical influences, children's socioeconomic background also can affect their perception of thermal comfort in primary schools [65]. In particular, their thermal perception in the classroom can reflect the thermal experiences at home. Trebilcock et al. [72,73] stated that children from highly vulnerable backgrounds were comfortable at lower temperatures than those from less vulnerable. However, the effect of socioeconomic background on the thermal perceptions of students is not sufficiently addressed by existing studies.

\subsubsection{Mechanical Ventilation}

According to a previous study, the children also preferred 'cooler-than-neutral' temperatures in mechanically ventilated classrooms [62,74]. Specifically, exposing to the same thermal environmental, the preferred temperature for children is estimated to be $2-3 \mathrm{~K}$ below the neutral one predicted for adults $[62,74]$. In 'cooler-than-neutral' indoor environment, the academic performance for children in standardized tests could increase by $2-4 \%$ with a reduction of the indoor temperature by $1{ }^{\circ} \mathrm{C}$ [75]. In addition, children are more vulnerable to uncomfortable environmental conditions than adults [76]. Therefore, uncomfortable environmental conditions affect children more significantly than adults.

Recent studies found that the majority of the children in school suffer from allergy, atopic dermatitis, asthma, etc., due to the inappropriate and crowded learning environment [77]. Under this situation, MV becomes more significant to increase the ventilation flow rate and help achieve thermal comfort, as addressed in many relevant studies. Rashidi et al. [78] demonstrated that sufficient ventilation of classrooms is necessary by either installing air handling units (AHU) or having compulsory breaks between lectures. The study also pointed out that classrooms air-conditioned with split units could not take in fresh air regularly [78]. Wang et al. [45] illustrated that classrooms of passively designed school buildings could provide better thermal comfort with optimized HVAC control systems. Mumovic et al. [79] concluded that a hybrid ventilation system coupling MV and NV is much more effective than running MV alone due to less exposure to noise or cold draught. Hybrid ventilation modes with high energy efficiencies without sacrificing thermal comfort may become future research directions.

Passive building design parameters (e.g., orientation, furniture layout) can influence the occupants' thermal perceptions even in classrooms with MV. Conceição et al. [80] concluded that classrooms with windows backing to the sun, the classrooms with sun shadings and interior spaces without windows present the worst thermal conditions in winter. The study suggested that uncomfortable occupied space needs to be ventilated and heated to simultaneously improve thermal comfort and air quality to suitable levels. Moreover, it was also found that solar radiation incoming from a south-facing window in winter could improve the indoor thermal conditions but may do the opposite in summer [80]. Optimal configuration of the window to wall ratios (WWRs) and building orientations can improve the indoor environment and reduce corresponding MV energy consumption through controlling the natural ventilation and limiting the thermal load. Building energy simulation-based multi-objective optimization with high efficiency and accuracy is a robust and promising approach to optimized passive design. It can automatically predict energy consumption and search for optimal solutions based on the specified design criteria and is therefore suggested as a potential research method in this area [81].

Furthermore, adaptive activities could also impact children's thermal comfort in airconditioned space [62]. Wang et al. [82] studied primary and secondary school students' thermal adaptation during the heating season in rural regions. The results illustrated that students showed a tolerance for a slightly cold indoor environment, so that is suggested to main a slightly lower indoor temperature to save heating energy while maintaining their thermal comfort [82]. Due to varied climate and the temperature increase, avoiding overheating and keeping thermal comfort in school buildings is becoming a growing 
concern [76]. In order to improve the energy efficiency and level of thermal comfort, Mohamed et al. [59] suggested that the heating system should be operated based on the actual outdoor climate through the whole heating season, subject to part-load operations in the early or late periods.

Table 3. Thermal comfort parameters proposed in studies on primary and secondary schools.

\begin{tabular}{|c|c|c|c|c|c|c|c|}
\hline Reference & Country & $\begin{array}{l}\text { School } \\
\text { Types }\end{array}$ & Time of Survey & $\begin{array}{l}\text { Operation } \\
\text { Types }\end{array}$ & $\begin{array}{l}\text { NO. of } \\
\text { Students }\end{array}$ & $\begin{array}{l}\text { NO. of } \\
\text { Schools }\end{array}$ & Age \\
\hline Mors et al. [19] & Netherlands & $\mathrm{P}$ & $\begin{array}{l}24 \text { days, including winter, } \\
\text { spring, summer, } 2010\end{array}$ & NV & 79 & 1 & $9-11$ \\
\hline Aparicio et al. [50] & Spain & $\mathrm{P}$ & summer & $\mathrm{NV}+\mathrm{MV}$ & 67 & 1 & $10-11$ \\
\hline Kim et al. [62] & Australia & $P+S$ & $\begin{array}{l}\text { Two summer seasons } \\
\text { (2012-2013) }\end{array}$ & MV & - & 11 & $\begin{array}{l}10-15 ; \\
16-18\end{array}$ \\
\hline Hamzah et al. [63] & Australia & S & - & NV & 1594 & 8 & - \\
\hline Montazami, et al. [65] & UK & $\mathrm{P}$ & $\begin{array}{l}\text { Cooling season } \\
\text { (2014-2015) }\end{array}$ & MV & 662 & 8 & $8-11$ \\
\hline Vassella, et al. [40] & Swiss & S & $\begin{array}{l}\text { winters } \\
\text { outside the heating }\end{array}$ & NV & - & 96 & - \\
\hline Teli, D., et al. [66] & UK & $\mathrm{P}$ & $\begin{array}{l}\text { season. } \\
\text { June and July } 2012\end{array}$ & NV & 560 & 2 & $7-11$ \\
\hline Teli, D., et al. [67] & UK & $P$ & $\begin{array}{c}\text { April to July } 2011 \\
\text { during Non-Heating }\end{array}$ & NV & 230 & 1 & $7-11$ \\
\hline Korsavi et al. [71] & UK & $P$ & $\begin{array}{c}(\mathrm{NH}) \text { and } \\
\text { Heating }(\mathrm{H}) \text { seasons }\end{array}$ & NV & 805 & - & $9-11$ \\
\hline Corgnati et al. [69] & Italy & $\mathrm{S}+\mathrm{U}$ & $\begin{array}{c}\text { Heating period from } 15 \\
\text { October to } 15 \text { April in } \\
2002\end{array}$ & $\mathrm{NV}+\mathrm{MV}$ & - & 4 & - \\
\hline Giuli et al. [70] & Italy & $\mathrm{P}$ & $\begin{array}{c}\text { Spring, } 2010 \\
\text { winter (July-August) and }\end{array}$ & NV & 614 & - & $9-11$ \\
\hline Trebilcock et al. [72,73] & Chile & $\mathrm{P}$ & $\begin{array}{c}\text { spring } \\
\text { (November-December) }\end{array}$ & NV & 440 & 12 & $9-10$ \\
\hline Wargocki et al. [76] & Denmark & $\mathrm{P}$ & $\begin{array}{l}\text { summer (in } 2004 \text { and } \\
2005\end{array}$ & MV & - & - & $6-16$ \\
\hline Ukawa et al. [77] & Japan & $\mathrm{P}$ & - & - & 4254 & 12 & $6-12$ \\
\hline Al-Rashidi, et al. [78] & Kuwait & $\mathrm{P}$ & 16-27 May 2010 & $\mathrm{NV}+\mathrm{MV}$ & - & - & $6-10$ \\
\hline Mumovic et al. [79] & UK & $\mathrm{S}$ & 2006-2007 & $\mathrm{NV}+\mathrm{MV}$ & - & - & - \\
\hline Conceição et al. [80] & Portugal & - & January 2004 & MV & - & 800 & - \\
\hline Liang et al. [83] & China & $P+S$ & $\begin{array}{l}1 \text { September } 2005 \text { to } 5 \\
\text { February } 2006\end{array}$ & NV & - & - & - \\
\hline Pereira et al. [84] & Portugal & S & $\begin{array}{c}\text { From the end of April } \\
\text { until } \\
\text { mid May } 2013\end{array}$ & NV & - & - & - \\
\hline Wang et al. [82] & China & S & $\begin{array}{l}\text { November } 2014 \text { to } \\
\text { December } 2015\end{array}$ & MV & 1126 & 13 & - \\
\hline Katafygiotou et al. [85] & Cyprus & S & $\begin{array}{l}\text { September to June in next } \\
\text { year }\end{array}$ & MV & 20 & 1 & - \\
\hline
\end{tabular}

Notes: P: primary school; S: secondary school.

From about literature review, it can be concluded that primary and secondary school children prefer colder indoor temperatures than adults for their thermal comfort in both naturally or mechanically ventilated classrooms. Considering that children are more vulnerable to inappropriate environmental conditions than adults, a precise prediction and control of the indoor thermal environment is important for improving their academic performance and health. However, the commonly used comfort models mainly derived from adult-based experiments cannot offer accurate predictions of children's thermal perception. Compared with MV, a hybrid ventilation mode is much more effective given its good acoustic and thermal performances.

\subsection{Thermal Comfort in Universities}

University students are adults with ages over 18. Compared to primary and secondary school students, they are subject to multidisciplinary and multi-functional environments [85,86]. Moreover, university students vary in age, gender, thermal background and taken programs and class types, adding the difficulties in evaluating the indoor envi- 
ronmental quality and analyzing their thermal perceptions $[85,86]$. Thus, indoor thermal analysis in varied university buildings becomes increasingly significant. The references reviewed in this section have been listed in Table 4, demonstrating the basic research information, such as ventilation operation modes and so on.

\subsubsection{Natural Ventilation (NV)}

Natural ventilation (NV), such as opening doors or windows, is commonly used in university buildings, with zero-energy consumption and convenient operation. Adjusting doors or windows to achieve indoor thermal comfort can be treated as adaptive behaviours. One noticeable difference from students of lower grades is that university students can adopt more adaptive behaviours, such as clothing adjustment and window operation [52,87-89]. This subsection reviews studies focusing on natural ventilation systems within universities. Kumar et al. [89] conducted a transverse questionnaire-based thermal comfort field study to evaluate thermal preferences and understand students' behavioral adaptation in naturally ventilated classrooms under the tropical climate. Mishra et al. [90] got the preferred temperature of $26.4{ }^{\circ} \mathrm{C}$ in the hot and humid regions and found that $80 \%$ occupant satisfaction was achieved when the regression neutral temperature is near $29^{\circ} \mathrm{C}$ and the operative temperature varies between 22.1 and $31.5^{\circ} \mathrm{C}$. Moreover, the influence of gender on thermal perceptions cannot be ignored as indicated by Nico et al. [91]. Their study confirms that the thermal perceptions of students differ with gender, and the questionnaire-based results demonstrate that girls prefer higher temperatures than boys under the same thermal conditions because of their lower levels of activities and metabolism rate [91]. When assessing thermal comfort, selecting an appropriate model is necessary. The PMV-PPD model can be used for evaluating thermal perceptions of students in universities, but sometimes overestimates their thermal sensation as indicated by Zhang et al. [92].

In terms of University classrooms with NV, the influence of passive design (e.g., WWR, shading) over the indoor thermal environment varies significantly. Solar shading benefits the reduction of MV energy consumption in summer while doing the opposite in winter [20]. Krüger et al. [93] demonstrated that buildings with windows exposed to the sun usually suffered from thermal discomfort in summer, but contributed to thermal comfort in winter with more solar gains. Therefore, optimized passive design can not only reduce the energy consumption of ventilation or extra heating/cooling system, but also ensure the indoor thermal conditions within a comfort level.

Outdoor environmental and climatic conditions also influence the preferred thermal environments in classrooms. Corgnati et al. $[69,94]$ found that the thermal preference of students changed gradually from the cold season to the interim and warm seasons. Specifically, the results show a preference for slightly warm or warm environments during the heating season while neutral environments in the interim season. Baruah et al. [95] carried out a questionnaire-based thermal comfort study in warm and humid climates in spring. All subjects felt no extreme level of thermal discomfort in this study. In addition, Costa et al. [96] pointed out that poor maintenance of window frames compromised occupant comfort and suggested that the windows frames should be repaired and maintained regularly to enable efficient natural ventilation and reduce the need for thermal regulation. This study highlights the significance of building maintenance in reducing the requirement of MV. 
Table 4. Thermal comfort parameters survey conducted in universities.

\begin{tabular}{|c|c|c|c|c|c|c|c|}
\hline Reference & Country & $\begin{array}{l}\text { School } \\
\text { Types }\end{array}$ & Time of Survey & $\begin{array}{l}\text { Operation } \\
\text { Types }\end{array}$ & $\begin{array}{l}\text { NO. of } \\
\text { Students }\end{array}$ & $\begin{array}{l}\text { Classroom } \\
\text { Types }\end{array}$ & Age \\
\hline Jowkar et al. [86] & UK & $\mathrm{U}$ & $\begin{array}{c}\text { October and } \\
\text { November 2017; } \\
\text { January to March } \\
2018\end{array}$ & $\mathrm{NV}+\mathrm{MV}$ & 3000 & $\begin{array}{l}\text { Lecture } \\
\text { rooms; } \\
\text { Studios; } \\
\text { PC labs }\end{array}$ & - \\
\hline Krüger et al. [93] & Brazil & $\mathrm{U}$ & $\begin{array}{l}\text { August 2000; } \\
\text { January } 2001\end{array}$ & NV & & - & - \\
\hline Hwang et al. [97] & China & $\mathrm{U}$ & 2003-2004 & $\mathrm{NV}+\mathrm{MV}$ & 944 & - & - \\
\hline A. Mishra [87] & India & $\mathrm{U}$ & $\begin{array}{c}\text { January to April } \\
\text { in } 2013\end{array}$ & NV & 121 & Laboratories & $19-21$ \\
\hline Yao et al. [88] & China & $\mathrm{U}$ & $\begin{array}{c}\text { March } 2005 \text { to } \\
\text { May } 2006\end{array}$ & NV & 3621 & $\begin{array}{l}\text { Lecture } \\
\text { buildings }\end{array}$ & $16-40$ \\
\hline Kumar et al. [89] & India & $\mathrm{U}$ & $\begin{array}{l}\text { Peak summer } \\
\text { months }\end{array}$ & NV & 900 & - & - \\
\hline Mishra et al. [90] & India & $\mathrm{U}$ & $\begin{array}{l}\text { Autumn 2013; } \\
\text { Spring } 2014\end{array}$ & NV & 67 & - & - \\
\hline Nico et al. [91] & Italy & $\mathrm{U}$ & $1+$ & $\mathrm{NV}+\mathrm{MV}$ & 126 & - & - \\
\hline Corgnati et al. [94] & Italy & $\mathrm{U}$ & $\begin{array}{l}\text { Heating period, } \\
\text { January to April } \\
\text { in } 2002\end{array}$ & NV & 230 & - & - \\
\hline Costa et al. [96] & Brazil & $\mathrm{U}$ & $\begin{array}{l}\text { Februauy, March, } \\
\text { April in } 2017\end{array}$ & $\mathrm{NV}+\mathrm{MV}$ & 178 & - & $18-67$ \\
\hline Jing et al. [98] & China & $\mathrm{U}$ & December 2018 & MV & 40 & - & - \\
\hline Mishra et al. [99] & Netherlands & $\mathrm{U}$ & $\begin{array}{c}\text { Heating season, } \\
\text { March } 2016\end{array}$ & MV & 384 & - & - \\
\hline Fanga et al. [100] & $\begin{array}{l}\text { Hong Kong, } \\
\text { China }\end{array}$ & $\mathrm{U}$ & $\begin{array}{c}\text { August to } \\
\text { October in } 2015\end{array}$ & MV & 982 & - & - \\
\hline Wang et al. [101] & China & $\mathrm{U}$ & $\begin{array}{c}\text { October } 2013 \text { to } \\
\text { April } 2014\end{array}$ & MV & 30 & $\begin{array}{l}\text { Classrooms } \\
\text { and } \\
\text { dormitories }\end{array}$ & - \\
\hline Fong et al. [102] & $\begin{array}{l}\text { Hong Kong, } \\
\text { China }\end{array}$ & $\mathrm{U}$ & Summer & MV & 48 & 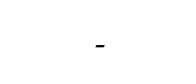 & $20-23$ \\
\hline Serghides et al. [103] & Cyprus & $\mathrm{U}$ & $\begin{array}{c}\text { winter and } \\
\text { summer of } 2012 \\
\text { and } 2013\end{array}$ & MV & 60 & - & - \\
\hline
\end{tabular}

Notes: U: University.

\subsubsection{Mechanical Ventilation (MV)}

Compared with NV classrooms in universities, students' thermal perceptions of MV classrooms are related to multiple factors. Hwang et al. [97] demonstrated that thermal perceptions of students were significantly related to the air temperature, wind speed and solar isolation, while the influence of acoustic, lighting and IAQ aspects can be ignored [97]. Davidsson et al. [104] pointed out that thermal comfort is related to the heat recovery rate. Mishra et al. [99] assessed the thermal comfort perception of students through the class hours, and they found that the thermal perception varied primarily with the outdoor temperature, operative temperature, and their previous thermal conditions. After a 20-min adaption, the thermal perceptions became uniform gradually. Additionally, Corgnati et al. [69] found that gender can also influence thermal perceptions, and women generally prefer a warmer environment than men in MV-dominated classrooms [69].

The preferred comfort temperatures differ with types of rooms (e.g., lecture rooms, studios, libraries and personal computer laboratories). Jowkar et al. [86] found that students acquire a higher level of physiological and psychological thermal adaptation in the studios and individual computer laboratories than in the lecture rooms, owing to a higher level of freedom to adopt adaptive behaviours. Specifically, comfort temperature calculated by the Griffiths' method tends to be $1{ }^{\circ} \mathrm{C}$ higher in studios than lecture rooms and PC labs, and comfortable temperature is shown to be approximately $2{ }^{\circ} \mathrm{C}$ lower under heating 
mode compared to the free-running and cooling modes [86]. Wang et al. [101] compared the preferred temperatures within the classrooms and dormitories. The results indicated that the students feel comfortable in dormitories with a higher preferred temperature of $21^{\circ} \mathrm{C}$ than in classrooms where higher clothing insulation is expected. Therefore, applying different comfort standards corresponding to various class types and operation modes is necessary to reach an indoor thermal comfort level with lower energy consumption.

Rational control of MV systems contributes to providing comfortable temperatures by adjusting the relative humidity and airspeed. Fong et al. [102] investigated the acceptable thermal conditions under three ventilation strategies, including mixing ventilation, displacement ventilation, and exhaust types of stratum ventilations. The experimental results demonstrated that the third controlling strategy could satisfy the thermal perceptions of students with the lowest ventilation energy consumption due to the higher preferred temperatures. Fanga et al. [100] illustrated a significant difference between the neutral and preferred temperatures of classrooms with MV in tropical regions, which were found to be $24.14{ }^{\circ} \mathrm{C}$ and $24.58{ }^{\circ} \mathrm{C}$, respectively. Jing et al. [98] carried out a field survey in Taiyuan of China. The results illustrated that $3.46 \%$ of the annual heating load could be saved when the indoor design temperature could decrease from $21.85^{\circ} \mathrm{C}$ to $19^{\circ} \mathrm{C}$. Serghides et al. [103] focused on the indoor comfort and energy consumption in university buildings during the winter. According to the results, using air conditioners and other indoor equipment only during the occupation periods instead of $24 \mathrm{~h}$ can save up to $40 \%$ of energy consumption.

\subsection{Research Gapes and Recommendations}

This section discussed the importance of thermal comfort for different educational buildings. Due to the significant role of ventilation in evaluating and optimizing indoor thermal conditions, the reviewed works are classified by natural ventilation and mechanical ventilation.

Ventilation interacts tightly with the indoor thermal environment. The ventilation can improve the relative humidity and control the air speed and temperature, keeping the acceptable PMV and PPD range. Undeniably, natural ventilation is subject to the local climates, and mechanical ventilation suffers from extra operation costs and energy consumption. Therefore, using a mixed-mode combining natural and mechanical ventilation effectively reduces energy consumption and operation cost without sacrificing thermal comfort. For instance, in spring and autumn, the proportion of NV time can be extended appropriately. It should be noticed that indoor comfort targets and mode switch algorithms significantly influence the mixed system's energy performance. Therefore, smart sensors and machine learning algorithms can be integrated into the control system to analyze and predict students' preferences, achieving both targets in energy and IEQ. Besides, special ventilation methods such as the stratum ventilation system can produce acceptable air flow to meet thermal demands with a lower ventilation rate and corresponding energy consumption. Some passive design measures can be coupled with efficient ventilation methods, depending on the availability of renewable energy sources.

The thermal acceptance analysis in universities is complicated due to more adaptation behaviours that can be adopted by students, and the relevant studies also started later than those on primary and secondary schools. The gender difference can also influence the thermal perceptions of students, but existing prediction models fail to take this factor into account. It has been found that children generally prefer cooler temperatures. Therefore, most existing models cannot accurately predict the thermal perceptions of children. Therefore, gender-specific and children-centric evaluation models and standards should be developed in future studies combining well-designed surveys and experiments.

\section{The Studies on Indoor Air Quality (IAQ)}

Indoor air quality (IAQ) significantly influences people's health, especially for children in kindergartens and primary schools. Additionally, for secondary schools and universities, due to the intensive population and activities, the concentration of contaminants generated 
by students may be higher than that in other places. For this reason, experiments, analytical assessment models and statistical analysis of IAQ are necessary, which not only offer students healthy environments but also improve their studying efficiency.

In general, there are two methods to measure IAQ-related parameters [35]. The first method is continuous IAQ monitoring for a specified period of time. It records IAQ parameters, such as $\mathrm{CO}_{2}, \mathrm{CO}, \mathrm{SO}_{2}, \mathrm{NO}_{2}, \mathrm{H}_{2} \mathrm{~S}, \mathrm{PM}_{2.5}, \mathrm{PM}_{10}$, and total volatile organic compounds (TVOCs), for several hours and even longer. The measurement results are strongly associated with occupants' activities. The second method is the passive IAQ measurement, which does not show the varying profiles of concentrations over time, for parameters such as volatile organic compounds (VOCs), aldehydes, toluene and aldehydes. Noticeably, among all the indoor contaminants, $\mathrm{PM}_{2.5}$ and $\mathrm{CO}_{2}$ are indoor air pollutions of major concern [37]. The evaluations models are described in the following parts, and the relevant models are summarized in Table 5 . The references reviewed in this section have been listed in Table 6, including the basic research information.

\subsection{IAQ Assessment Model}

This section will discuss the analytical model for determining the concentrations of indoor contaminants.

$\mathrm{CO}_{2}$ as an essential indicator is commonly used to assess ventilation rates. Equation (1) in Table 5 shows an evaluation model for $\mathrm{CO}_{2}$. This model, as a time-dependent method, considers the indoor $\mathrm{CO}_{2}$ sources, outdoor $\mathrm{CO}_{2}$ levels and the influence of ventilation. The drawback for this model is that it needs to monitor the data continually as input to the evaluation models for further prediction. As for the prediction and evaluation for PM, there is no single model suitable for dealing with all PM-related problems because of the interaction among the different sized PM. Precisely, different models correspond to PM with different sizes. Equation (2), based on the theory of sequentially mass conservation, shows an assessment model for PM, considering the mechanical supply, natural ventilation and infiltration. Equation (3) is a mass balance equation for continuous VOCs concentration computation. The indoor $\mathrm{NO}_{2}$ concentration depends significantly on the surface removal rate and outdoor $\mathrm{NO}_{2}$ levels. If there is no indoor $\mathrm{NO}_{2}$ source, the indoor to the outdoor ratio of $\mathrm{NO}_{2}$ can be calculated by Equation (4). However, if there are some indoor $\mathrm{NO}_{2}$ sources, this model is not applicable. At a constant air exchange rate, the ratio between indoor and outdoor $\mathrm{O}_{3}$ concentrations can be quantified by Equation (5).

Table 5. IAQ assessment model [39].

\begin{tabular}{ccc}
\hline $\begin{array}{c}\text { Evaluated } \\
\text { Parameter }\end{array}$ & \multicolumn{1}{c}{ Analytical Model } & Limitation \\
\hline$C_{\mathrm{co}_{2}}=\mathrm{C}_{0}+\frac{G}{Q}+\left(\mathrm{C}_{0}-\mathrm{C}_{\text {out }}-\frac{G}{Q}\right) e^{-\frac{Q}{V} t}$ & $(1)$ & $\begin{array}{c}\text { Require to continue to monitor the data as } \\
\text { input for the evaluation models, such as } \\
\text { real-time occupancy. }\end{array}$ \\
$\mathrm{CO}_{2}$ & $\begin{array}{l}\mathrm{G}=\text { the generation rate, } \mathrm{m}^{3} / \mathrm{s} ; \mathrm{C}_{\text {out }}=\text { outdoor } \mathrm{CO}_{2} \\
\text { concentrations, } \mathrm{ppm} ; \mathrm{C}_{0}=\mathrm{initial} \text { indoor } \mathrm{CO}_{2} \text { concentrations, } \\
\mathrm{ppm} Q \mathrm{Q}=\text { ventilation rates, } \mathrm{m}^{3} / \mathrm{s} ; V=\text { the volume of indoor } \\
\text { air, } \mathrm{m}^{3} ; \mathrm{t}=\text { time, } \mathrm{s} .\end{array}$ \\
\hline
\end{tabular}


Table 5. Cont.

PM

VOCs

$\mathrm{NO}_{2}$

$\mathrm{O}_{3}$
$C_{\text {out }}=$ outdoor particles concentrations, $\mu \mathrm{g} / \mathrm{m}^{3}$;

$Q_{\mathrm{s}}=$ mechanical ventilation flow rate, $\mathrm{m}^{3} / \mathrm{h}$;

$Q_{\mathrm{N}}=$ natural ventilation rate, $\mathrm{m}^{3} / \mathrm{h} ; Q_{\mathrm{L}}=$ leakage flow rate, $\mathrm{m}^{3} / \mathrm{h} ; P=$ the penetration rate of leakage flow path; $\eta_{\mathrm{s}}=$ single-pass removal efficiency filtered by mechanically operated supply; $Q_{\mathrm{F}}=$ the flow rate of a particle-control filter, $\mathrm{m}^{3} / \mathrm{h} ; \eta_{\mathrm{F}}=$ single-pass removal efficiency of a practical-control filter; $E=$ emission source rate, $\mu \mathrm{g} / \mathrm{h}$; $\xi=$ a deposition rate of particles onto room surface, $\mathrm{h}^{-1}$; $V=$ space volume, $\mathrm{m}^{3} ; C_{\text {in }}=$ indoor particles concentrations.

$$
V \frac{d\left(C_{i n}\right)}{d t}=Q C_{a}+\sum_{i} E_{s o i} A_{s o i}-\sum_{j} S_{s i j} A_{s i j}-Q C_{o u t}
$$

$V=$ the volume of the zone, $\mathrm{m}^{3} ; C_{\text {in }}=$ the VOCs

concentration in the zone, $\mu \mathrm{g} / \mathrm{m}^{3} ; t=$ time, $\mathrm{s} ; Q=$ ventilation rate of the zone, $\mathrm{m}^{3} / \mathrm{s} ; C_{\mathrm{a}}=$ the compound concentration at the supply inlet, $\mu \mathrm{g} / \mathrm{m}^{3} ; E_{\mathrm{soi}}=$ the emission rate per unit area of the source material $\mathrm{i}, \mathrm{g} / \mathrm{m}^{2} \cdot \mathrm{s} ; A_{\mathrm{soi}}=$ surface area of the source material $\mathrm{i}, \mathrm{m}^{2} ; S_{\mathrm{sij}}=$ absorption rate of sink material j, $\mathrm{g} / \mathrm{m}^{2} \cdot \mathrm{s} ; A_{\mathrm{sij}}=$ surface area of the sink material $\mathrm{j}$, $\mathrm{m}^{2} ; C_{\text {out }}=$ compounds concentration at outlet, $\mathrm{g} / \mathrm{m}^{3}$.

$$
\frac{I}{O}=\frac{E_{X}}{E_{X}+K_{N_{2}}}
$$

$E_{\mathrm{X}}=$ air exchange rate, $\mathrm{h}^{-1}$;

$K_{\mathrm{NO} 2}=$ the constant removal rate of the surface, $\mathrm{h}^{-1}$;

$$
\frac{I}{O}=\frac{E_{X}}{E_{X}+K_{d}(A / V)}
$$

$E_{\mathrm{X}}=$ air exchange rate, $\mathrm{h}^{-1} ; K_{\mathrm{d}}=$ the deposition velocity of ozone, $\mathrm{m} / \mathrm{h} ; A=$ total surface area, $\mathrm{m}^{2} ; V=$ the volume of the room, $\mathrm{m}^{3}$.
The outputs are significantly dependent on $\eta_{s}, \eta_{p}, \mathrm{P}$ and $\mathrm{E}$ which varies with PM sizes.

\subsection{Carbon Dioxide $\left(\mathrm{CO}_{2}\right)$}

The concentration of $\mathrm{CO}_{2}$ is mainly related to ventilation rates, the number of occupants, classroom sizes, activities, and the total time that occupants stay [105]. The respiration of occupants is the primary source of $\mathrm{CO}_{2}$ [105]. Besides, the vehicle's combustion of fossil fuels near the classroom also contributes to the indoor $\mathrm{CO}_{2}$ concentration [59]. In most studies, the $\mathrm{CO}_{2}$ concentration was monitored continuously to evaluate indoor ventilation levels [59]. Additionally, the measurement of $\mathrm{CO}_{2}$ also benefits in predicting trends of other indoor-generated gaseous pollutants in classrooms. However, It is hard to use $\mathrm{CO}_{2}$ levels to predict other dynamic pollutants generated outdoor and/or in the form of particles [106].

$\mathrm{CO}_{2}$ significantly influences the academic performance of both teachers and students. High $\mathrm{CO}_{2}$ concentration in the classroom means inadequate ventilation, which is a common problem in many schools $[6,105]$. For a healthy indoor environment, the $\mathrm{CO}_{2}$ concentration 
ranges from the indoor value of $380 \mathrm{ppm}$ to $1500 \mathrm{ppm}$ reported by ESFA as an acceptable value for occupants that do not feel uncomfortable [107]. For green buildings, the corresponding value should be smaller than $1000 \mathrm{ppm}$ [107]. When the concentration is greater than 200,000 ppm extremely, death is induced [107].

The dynamic feature of the concentration of $\mathrm{CO}_{2}$ in educational buildings is more evident, significantly differing from other buildings such as commercial buildings and residential buildings. Specifically, the $\mathrm{CO}_{2}$ concentration profiles over time in education buildings demonstrate strongly inherent relationships with the class schedules [35]. At the beginning of the class schedule (9:00 a.m. usually), $\mathrm{CO}_{2}$ concentration increases and reaches the maximum at the end of the class [35]. Then, the $\mathrm{CO}_{2}$ concentration decreases suddenly in the class breaks due to the break-time outdoor activities [35]. In addition to the teaching hours, which corresponds to the highest contribution of low IAQ, the role of the afternoon nap is also important [108]. In contrast, the $\mathrm{CO}_{2}$ in commercial and residential buildings levels off considerably lower with slight fluctuations due to no strict time schedules [108].

It was noted that improving ventilation and decreasing the number of occupancy following occupancy periods can alleviate high $\mathrm{CO}_{2}$ concentration [108]. Under this situation, ventilation systems become crucial to keep the concentration of $\mathrm{CO}_{2}$ under the guidelines during class time. It was pointed out that both the mechanical ventilation systems and automatic opening windows benefit the classroom for keeping a lower level of $\mathrm{CO}_{2}$ in comparison with the manual opening of windows and doors [109], and mechanical ventilation is relatively efficient to remove the $\mathrm{CO}_{2}$ and allow more occupants to stay in the classroom simultaneously [110]. If energy consumption is not considered, continuous ventilation during the day and night is the other most efficient and effective way to passively cool educational spaces [111]. After adopting the appropriate ventilation strategies, the $\mathrm{CO}_{2}$ concentration can significantly decrease from $3000 \mathrm{ppm}$ to $530 \mathrm{ppm}$ during breaking time [112].

\subsection{Particulate Matter (PM)}

Particulate Matter (PM) is a kind of small particle in the atmosphere. The detriment to occupants' bodies is mainly related to the size of the aerosols because of the increasing capacity of penetration in the respiratory tract with decreasing size of particulate matter (PM) [113]. Specifically, the PM with an equivalent diameter smaller than $2.5 \mu \mathrm{m}$, defined as $\mathrm{PM}_{2.5}$, can pass through the pulmonary alveoli and reach the bloodstream [114]. The PM with an equivalent diameter between $2.5 \mu \mathrm{m}$ and $10 \mu \mathrm{m}$ could be breathed into the tracheobronchial zone, defined as $\mathrm{PM}_{10}$ [114]. Long-time exposure to $\mathrm{PM}_{2.5}$ and $\mathrm{PM}_{10}$ increases the opportunities of asthma-like symptoms in children in school environments [114].

Many reasons caused the unacceptable concentration levels of $\mathrm{PM}_{2.5}$ and $\mathrm{PM}_{10}$. The influence of room occupancy on indoor particle concentrations varies with particle sizes. Specifically, Poupard et al. [115] stated that the infiltration of outdoor pollutants is the primary source of indoor $\mathrm{PM}_{2.5}$, to which motor vehicle emission by products contribute the largest portion [115]. Becerra et al. [35], Chan et al. and Yang et al. [116,117] found that indoor $\mathrm{PM}_{10}$ seems to be dependent on the particle suspension due to the occupant's activity, such as cleaning, which can cause resuspension of these particles from carpet and furniture. Bennett et al. [36] found that the particle suspension was primarily composed of crustal matter (soil) elements brought by children's footwear and blackboard chalk use. Undoubtedly, high-density traffic areas can induce high PM concentrations as well [118].

Noticeably, based on the equivalent diameters of the PM, there exist different ways for reducing indoor PM concentrations. In order to prevent the outdoor $\mathrm{PM}_{2.5}$ from entering the indoor environments, Hou et al. [119] stated that closing windows and doors is conducive to lessening $\mathrm{PM}_{2.5}$, and the indoor concentrations of $\mathrm{PM}_{2.5}$ could be reduced by $40 \%$. For reduction of the $\mathrm{PM}_{10}$ concentration, taking the shoes off when entering the school buildings can significantly reduce the corresponding concentrations [118]. In addition, it was found that the indoor $\mathrm{PM}_{10}$ level of schools near the road with few vehicles was significantly lower than that of the schools near surrounding buildings and mountains [24]. 
Therefore, choosing rural areas with fewer pollutant sources as school sites may help reduce concentration levels of PM [24].

However, when doors and windows are closed, the ventilation rates in the classroom will be lower than $1 \mathrm{~L} / \mathrm{s}$ per person. In this case, although the $\mathrm{PM}_{2.5}$ level is low, the $\mathrm{CO}_{2}$ concentrations will exceed $2000 \mathrm{ppm}$, which is unacceptable for students inside the classroom [119]. Therefore, mechanical ventilation equipment with air filtration should be introduced into closed educational buildings [119]. It should be noticed that mechanical ventilation influences indoor PM concentrations significantly. Fromme et al. [34] demonstrated that the indoor PM levels interact strongly with the outdoor levels, which is attributed to the increased ventilation in spring, summer and autumn.

\subsection{VOCs and TVOC Concentrations}

Volatile organic compounds (VOCs) consist of many air pollutants, from volatile compounds, such as formaldehyde, to semi-volatile compounds, such as phthalate plasticizers $[35,114]$. The VOCs threaten the occupants' health if the corresponding concentrations exceed the standards or guidelines, especially for children and the elderly, because of their relatively vulnerable and sensitive immune systems [35,114]. Hutter et al. [120] concluded that the detriments of VOCs on health depend on several aspects, including (1) the type of VOCs, (2) the total amounts of VOCs and, 3) the exposure duration. Living with some VOCs for an extended period could increase cancer risks [120].

Total volatile organic compounds (TVOC) are usually used to represent the total performance of the various VOCs, which can be measured through continuous IAQ monitoring. A high concentration of TVOC induces sensory effects, including sensory irritation, dryness, and weak inflammatory irritation in the eyes and/or nose [35]. Similar to $\mathrm{CO}_{2}$, the concentration of TVOC also changes obviously over time. In the daytime, TVOC concentration starts to increase with the beginning of the class schedule, resulting from the indoor pollutant sources (e.g., by class activities and the specific equipment used) [35,107]. At night, TVOC concentrations, related to indoor pollutant sources significantly, keep a constant level approximately $[35,107]$. The indoor sources of TVOC usually include cleaning products, construction or furnishing materials and miscellaneous consumer products [35].

Mechanical ventilation is a significant factor for improving the IAQ by removing the VOCs. Noticeably, because of the absence of mechanical ventilation, TVOC concentrations are over three times higher in the more airtight rooms. By using mechanical ventilation, Hernandez et al. [121] found that TVOC concentrations can be reduced by $>340 \mu \mathrm{g} / \mathrm{m}^{-3}$ in less airtight rooms. Hu et al. [122] proposed an improved strategy for reducing indoor VOCs pollutions. This method adopts the average concentration of VOCs as the optimization objective. The optimization results suggest that the inflowing air needs to flow preferentially to the places with high VOCs concentration to remove excessive VOCs and reduce the average concentration. However, there are few studies focusing on indoor educational environments.

\subsection{Other Pollutants: $\mathrm{NO}_{2}, \mathrm{SO}_{2}$, and $\mathrm{O}_{3}$}

$\mathrm{NO}_{2}, \mathrm{SO}_{2}$, and $\mathrm{O}_{3}$ are other critical factors related to the health of students. A high concentration of air pollutions mentioned above causes the respiratory distress-like syndrome, which deserves detailed studies. It was reported that the concentration of $\mathrm{SO}_{2}$ is at a similar level for both urban and suburban areas, illustrating that the vehicular traffic and the petrochemical plant present a similar potential for $\mathrm{SO}_{2}$ emissions [6]. On the contrary, the indoor $\mathrm{NO}_{2}$ and $\mathrm{O}_{3}$ concentrations have strong and positive correlations with the levels of outdoor contaminants. The concentration of $\mathrm{NO}_{2}$ and $\mathrm{O}_{3}$ varies significantly with the location of school buildings [6]. Specifically, compared with schools in rural regions, the urban schools have higher $\mathrm{NO}_{2}$ values resulting from the vehicular emissions proved to be an essential source of $\mathrm{NO}_{2}$ in the atmosphere [7,31]. Noticeably, except for the occupancy and the school locations, the climates also affect the performance of the indoor environmental parameters. For instance, it was found that $\mathrm{O}_{3}$ concentrations are significantly higher 
in the cold season, while $\mathrm{CO}$ and $\mathrm{NO}_{2}$ concentrations are relatively higher in the warm season [34,37].

\subsection{Research Gaps and Recommendations}

Generally, adequate ventilation can improve IAQ and thermal comfort [24,123]. Good ventilation strategies in educational buildings reduce the level of indoor air pollution. Building ventilation systems and outdoor concentration levels greatly affect indoor-tooutdoor ratios through the introduced fresh air, leading to complex, homogeneous and heterogeneous processes [115]. However, natural ventilation, such as opening windows between class changes or lunch breaks, may result in higher ultrafine particle levels measured indoors. It may be due to the infiltration of pollutants from the outdoors. Some IAQ-related concentrations usually stabilize at a constant value over the weekend. But the concentrations of the other pollutant, such as $\mathrm{CO}_{2}$, increase to higher levels at the beginning of the working day due to the increase in the number of students/occupancy and activities.

On the contrary, $\mathrm{NO}_{2}$ and $\mathrm{O}_{3}$ showed fewer regular fluctuations during occupancy. Therefore, it is concluded that the air permeability of the building envelope and the manual ventilation of the classroom cannot simultaneously reduce the concentration level of various pollutants in the classroom [106]. Thus, an improved mixed control strategy for ventilation is needed, and mechanical ventilation with a function of filtration is necessary to solve the above problems [106] effectively. Moreover, the quality of outdoor air used to provide ventilation needs to be considered [124]. Choosing locations close to rural areas for new schools can significantly improve air quality and healthier environments in schools $[24,125]$.

In addition, most research focuses on primary schools, followed by nursery and secondary schools, while little attention is paid to IAQ in the university as summarized in Table 5. There are 15 articles focusing on primary school, followed by 6 articles on the nursery, 5 on secondary school, and 2 on the university. As for studied parameters, 21 articles focused on the $\mathrm{CO}_{2}$, followed by 18 articles on PM, 9 articles on $\mathrm{NO}_{2}, 9$ articles on VOC and TVOC, and 6 articles on CO, etc. Obviously, most IAQ studies concentrate on primary schools, while few on the universities. Among these studies, $\mathrm{CO}_{2}$ and $\mathrm{PM}$ as significant IAQ parameters attract more attention. Undoubtedly, there is a lack of research on bacterial and fungal aerosol pollutants to comprehensively assess IAQ in nurseries, secondary schools, and universities. These research gaps need to be bridged by more comprehensive measurement and assessment approaches.

Table 6. IAQ parameters monitoring for different types of schools.

\begin{tabular}{|c|c|c|c|c|c|c|c|c|c|c|c|c|}
\hline \multirow{2}{*}{ Reference } & \multirow{2}{*}{$\begin{array}{l}\text { School } \\
\text { Types }\end{array}$} & \multicolumn{9}{|c|}{ Continuous IAQ Monitoring } & \multicolumn{2}{|c|}{$\begin{array}{l}\text { Passive IAQ } \\
\text { Monitoring }\end{array}$} \\
\hline & & $\mathrm{CO}_{2}$ & $\mathrm{SO}_{2}$ & $\mathrm{NO}_{2}$ & $\mathrm{H}_{2} \mathrm{~S}$ & TVOC & PM & $\mathrm{CO}$ & $\mathrm{O}_{3}$ & TSP & VOC & Aldehydes \\
\hline Hemoud et al. [126] & $\mathrm{P}+\mathrm{S}$ & $\sqrt{ }$ & $\sqrt{ }$ & $\sqrt{ }$ & $\sqrt{ }$ & $\sqrt{ }$ & $\sqrt{ }$ & & & $\sqrt{ }$ & & \\
\hline Becerra et al. [35] & $\mathrm{N}+\mathrm{P}+\mathrm{S}$ & $\sqrt{ }$ & & & & & $\sqrt{ }$ & & & & $\sqrt{ }$ & $\sqrt{ }$ \\
\hline Bennett et al. [36] & $\mathrm{P}$ & $\sqrt{ }$ & & $\sqrt{ }$ & & & $\sqrt{ }$ & & & & & \\
\hline Branco et al. [37] & $\mathrm{N}+\mathrm{P}$ & $\sqrt{ }$ & & $\sqrt{ }$ & & $\sqrt{ }$ & & $\sqrt{ }$ & & $\sqrt{ }$ & & \\
\hline Cai et al. [110] & $\mathrm{N}+\mathrm{P}+\mathrm{S}$ & $\sqrt{ }$ & & & & & $\sqrt{ }$ & & & & & \\
\hline Chithra et al. [3] & - & & & & & & $\sqrt{ }$ & $\sqrt{ }$ & & & & \\
\hline Fromme et al. [34] & $\mathrm{P}+\mathrm{S}$ & $\sqrt{ }$ & & & & & $\sqrt{ }$ & & & & & \\
\hline Godoi et al. [7] & $\mathrm{P}$ & & $\sqrt{ }$ & $\sqrt{ }$ & & $\sqrt{ }$ & & & & & & \\
\hline Haddad et al. [127] & S & $\sqrt{ }$ & & & & & $\sqrt{ }$ & & & & $\sqrt{ }$ & \\
\hline Hou et al. [119] & $\mathrm{P}$ & $\sqrt{ }$ & & & & & $\sqrt{ }$ & & & & & \\
\hline Jovanović et al. [128] & $\mathrm{P}$ & $\sqrt{ }$ & & $\sqrt{ }$ & & & & & $\sqrt{ }$ & & $\sqrt{ }$ & \\
\hline Kalimeri et al. [6] & $\mathrm{N}+\mathrm{P}$ & $\sqrt{ }$ & & $\sqrt{ }$ & & & & & $\sqrt{ }$ & & & $\sqrt{ }$ \\
\hline Leppanen et al. [118] & & & & & & & $\sqrt{ }$ & & & & & \\
\hline Madureira et al. [114] & $\mathrm{P}$ & $\sqrt{ }$ & & & & & $\sqrt{ }$ & & & & $\sqrt{ }$ & $\sqrt{ }$ \\
\hline Mainka et al. [108] & $\mathrm{N}$ & $\sqrt{ }$ & & & & & $\sqrt{ }$ & & & & $\sqrt{ }$ & \\
\hline Majd et al. [125] & $\mathrm{P}$ & & & $\sqrt{ }$ & & & $\sqrt{ }$ & $\sqrt{ }$ & & & & \\
\hline Mohamed et al. [129] & $\mathrm{P}$ & $\sqrt{ }$ & & & & & $\sqrt{ }$ & & & & & \\
\hline Poupard et al. [115] & - & $\sqrt{ }$ & & $\sqrt{ }$ & & & & & $\sqrt{ }$ & & & \\
\hline Rivas et al. [31] & - & $\sqrt{ }$ & & & & & $\sqrt{ }$ & & & & & \\
\hline Sohn et al. [130] & - & $\sqrt{ }$ & & & & $\sqrt{ }$ & $\sqrt{ }$ & $\sqrt{ }$ & & & & \\
\hline
\end{tabular}


Table 6. Cont.

\begin{tabular}{|c|c|c|c|c|c|c|c|c|c|c|c|c|}
\hline \multirow{2}{*}{ Reference } & \multirow{2}{*}{$\begin{array}{l}\text { School } \\
\text { Types }\end{array}$} & \multicolumn{9}{|c|}{ Continuous IAQ Monitoring } & \multicolumn{2}{|c|}{$\begin{array}{l}\text { Passive IAQ } \\
\text { Monitoring }\end{array}$} \\
\hline & & $\mathrm{CO}_{2}$ & $\mathrm{SO}_{2}$ & $\mathrm{NO}_{2}$ & $\mathrm{H}_{2} \mathrm{~S}$ & TVOC & PM & $\mathrm{CO}$ & $\mathrm{O}_{3}$ & TSP & VOC & Aldehydes \\
\hline Stabile et al. [106] & - & $\sqrt{ }$ & & & & & $\sqrt{ }$ & & & & & \\
\hline Theodosiou et al. [131] & $\mathrm{N}+\mathrm{P}$ & $\sqrt{ }$ & & & & & & & & & & \\
\hline Yang et al. [24] & $\mathrm{P}$ & $\sqrt{ }$ & & $\sqrt{ }$ & & & $\sqrt{ }$ & $\sqrt{ }$ & & & & $\sqrt{ }$ \\
\hline Alves et al. [132] & $\mathrm{U}$ & $\sqrt{ }$ & & & & & $\sqrt{ }$ & $\sqrt{ }$ & & & & \\
\hline Fan et al. [133] & $\mathrm{U}$ & $\sqrt{ }$ & & & & & & & & & & \\
\hline
\end{tabular}

Notes: N: nursery; P: Primary school; S: Secondary school; U: University.

\section{Ventilation Energy Consumption}

As an essential part of building services systems, the ventilation system can provide a preferable thermal environment and acceptable IAQ for occupants while is also responsible for a considerably large proportion of total energy consumption [134]. Energy consumption varies in response to ventilation modes, affecting the IAQ and thermal comfort in return. It was pointed out that schools have a great potential in improving energy efficiency [131]. In most climates, improving ventilation performances contribute to the reduction of urban energy consumption by up to $6.704 \%$, dominating the energy saving in temperate continental climate zones [135]. Stabile et al. [136] stated that it is possible to achieve a considerable reduction in energy consumption for MV systems. Therefore, optimizing ventilation control systems and building operation modes is necessary for reducing energy consumption without compromising thermal comfort and IAQ [137]. The interactions between IAQ, thermal comfort and ventilation energy are detailed in this subsection.

\subsection{Mechanical Ventilation (MV)}

Mechanical ventilation (MV) systems can simultaneously vary the indoor environment and energy consumption. Stabile et al. [138] illustrated that mechanical ventilation systems could effectively remove the indoor pollutants and reduce the indoor-tooutdoor concentration ratios, showing a higher efficiency in IAQ management than natural ventilation. It is recognized that MV has advantages in IAQ management over NV, and appropriate MV can also achieve energy-saving and thermal comfort regulation. Haghshenaskashani et al. [139] studied the impinging jet ventilation system, making thermal stratification possible with the lowest energy consumption. Such ventilation ensures a better IAQ and reduces energy consumption by up to 30\%. Jagadeesh et al. [140] analyzed the indoor temperature and airflow in the classroom using CFD and scaled-down experiments. The results illustrated that providing proper additional ventilation in the classroom enhances the natural circulation of air and reduces room temperature by $4{ }^{\circ} \mathrm{C}$ to $5{ }^{\circ} \mathrm{C}$, achieving the goal of energy saving in fans [140]. Using the mixed operation mode combing the MV and NV can improve the comfort and energy performance at the same time.

Proper MV before or after the occupation period for education buildings can provide an acceptable thermal indoor environment with the lowest energy cost. Wang et al. [141] stated that extra night ventilation could provide more satisfactory living conditions for the next day and reduce the electricity consumption for cooling in the daytime. Good ventilation decreases and increases the ventilation energy consumption in summer and winter, respectively, where overall energy demands are reduced for almost all climates with higher ventilation levels [135]. Gustafsson et al. [137] found that pre-ventilation before classes in the winter morning could improve IAQ and assist in heating the classrooms. Using passive design strategies assisted with MV can achieve the same purpose. Applying the phase change material may be a better choice besides optimizing the WWRs and building orientations for NV. Prabhakar et al. [142] reported that coupling the night ventilation and phase change material within the building envelope could reduce air-conditioning energy consumption. In addition, the sunspace is a noteworthy passive design measure as pointed out by Barrencua et al. [143]. Their experiment pointed out that combining the sunspace 
with the mechanical ventilation system could effectively reduce energy consumption with preheated air.

Apart from passive design, the smart building management system can adjust the airflow and cooling capacity to ensure sufficient air-conditioning and reduce energy consumption. According to a sensor-based monitoring system, Che et al. [144] reported that the moisture can be removed from the outdoor air in a hot and humid climate with a reduction of energy consumption by $50 \%$. Schibuola et al. [145] reported that using an autonomous high-efficiency air handling unit reduces energy consumption between $60 \%$ and $72 \%$. Wang et al. [146] demonstrated that the IAQ improvement and heating energy reduction could be achieved simultaneously via a novel heat recovery heat pump and ventilation system in the classroom.

\subsection{Natural Ventilation (NV)}

Natural ventilation (NV) is considered one of the most commonly used sustainable solutions to ensure healthy and comfortable indoor environments while consuming less energy than other ventilation strategies [147]. However, natural ventilation is limited by location and it alone cannot guarantee the IAQ. Huertas et al. [148] found that applying $\mathrm{NV}$ in coastal areas has a better performance than that in inland areas due to low-level outdoor pollutants. Therefore, natural ventilation should be used together with a portable air cleaner that can rapidly remove air pollution [149].

Ma'bdeh et al. [150] compared different natural ventilation retrofitting techniques in terms of the ventilation rate, indoor operative temperature, relative humidity, and $\mathrm{CO}_{2}$ concentration. Among these techniques, the solar chimney assisted with a wind tower can achieve the highest energy-saving of 39\% compared with baseline air conditioning systems. Harbich et al. stated that [151] applying natural ventilation or evaporative coolers, as an energy-saving and sustainable method, is sufficient to provide thermal comfort during the morning throughout autumn and winter. Though all-day natural ventilation contributes to reducing energy consumption, the overall uncomfortable periods increase. By contrast, exclusive use of air-conditioning could guarantee $100 \%$ hours of thermal comfort, but it is unacceptable for most families with high electricity bills [152]. Therefore, the mixed-mode based on the categories from EN 16798-1:2019 is recommended to save energy without sacrificing thermal comfort [152]. Moreover, internet of things (IoT) based or artificial intelligence (AI) based control can provide optimized solutions for mixed-mode ventilation to balance the NV and MV. Some preliminary researches have been carried out in this new area. For instance, based on the internet of things (IoT) system, Sung et al. [153] presented an application system that uses fuzzy control to provide thermal comfort for indoor environments. Yu et al. [154] presented a deep Q-learning method to balance the IAQ, thermal comfort, and energy consumption. Based on personal thermal preference, using smart algorithms to adjust the proportion of $\mathrm{NV}$ and MV provides a convenient and effective way to control the indoor thermal environment automatically.

The influence of the WWR on thermal comfort, IAQ and ventilation energy consumption cannot be ignored. The WWR mainly affects the natural ventilation flow rate and solar gain. Considering appropriate WWRs in the initial building design process can improve the indoor environmental quality and enhance students' concentration and productivity [155]. Reducing WWRs is also conducive to meeting the target energy reduction [156]. Ashrafin et al. [155] pointed out that a better-designed configuration of windows can improve thermal comfort by controlling the solar gain. Lakhdari et al. [157] suggested that the optimal WWRs are 30\%,40\%, and 50-60\% for north, south, and west/east orientations, respectively. Unfortunately, almost all WWR-related studies focus on residential buildings $[158,159]$ and commercial buildings $[156,160]$. It should be noted that the interactions between thermal comfort, window-related natural ventilation and energy cost differ between children and adults, which is worth more systematic investigations. 


\subsection{Research Gaps and Recommendations}

Thermal comfort, IAQ and ventilation energy consumption interact with each other in educational buildings. When the higher indoor temperature is preferred, occupants may suffer from poor IAQ, as the lower indoor temperature can suppress TVOC emissions and enhance occupants' tolerance of IAQ. It should be noted that thermal comfort is significantly associated with $\mathrm{CO}_{2}$ concentrations and $\mathrm{PM}$ background concentrations, where relative humidity (a crucial factor of thermal comfort) is also related to almost all kinds of indoor pollution sources. Optimal ventilation can control the indoor temperature, relative humidity and improve IAQ by removing pollutants with fresh air. It can also maintain thermal comfort and reduce energy consumption in heating or cooling systems.

It should be noticed that university buildings usually have different functional rooms such as libraries, chemistry laboratories, fitness rooms and theatre classrooms, requiring sufficient ventilation to meet safety and teaching requirements. Besides, university students have more diversified curriculum arrangements and a higher degree of freedom for adaptive behaviours compared with primary and secondary students. Therefore, different functional spaces require different thermal comfort and IAQ criteria to meet the diversified needs of the occupants while achieving energy saving. In addition, further research on bacterial and fungal aerosol pollutants in educational buildings is needed to evaluate IAQ comprehensively. Ventilation plays an essential role in the energy efficiency of educational buildings, given its correlation with thermal comfort and IAQ. Optimally controlled ventilation can provide a high-quality indoor environment with a reduction of heating and cooling energy consumption. Machine learning-based multi-objective optimization can be a promising method adopted for such future research.

Overall, the scope of future directions among thermal comfort, IAQ and ventilation energy is summarized in Figure 8. For thermal comfort, the prediction model should consider the influence of educational levels, gender and room types. The educational level-based evaluation model is conducive to assessing the occupants' thermal perceptions and improving the indoor thermal conditions. Some relevant standards and guidelines considering the factor of ages are also necessary. For the indoor thermal comfort monitoring, the influences of the climates, which affect the occupants' thermal experience and perceptions, cannot be ignored besides the education levels. In terms of IAQ, fewer studies focus on university occupants. It should be noticed that university students spend a long time within the indoor environment, and therefore requires more attention. As mentioned above, both the thermal comfort and IAQ interact with ventilation, and mixed ventilation modes are suggested for energy-saving purposes. Intelligent ventilation control systems, based on machine learning algorithms, which couple modeling, prediction and decision-making processes, can be used to balance the operation time between NV and MV. In such novel approaches, smart sensors (such as Apple Watch) can be applied to collect occupancy and personal physiological data as indicators for the intelligent control system. 


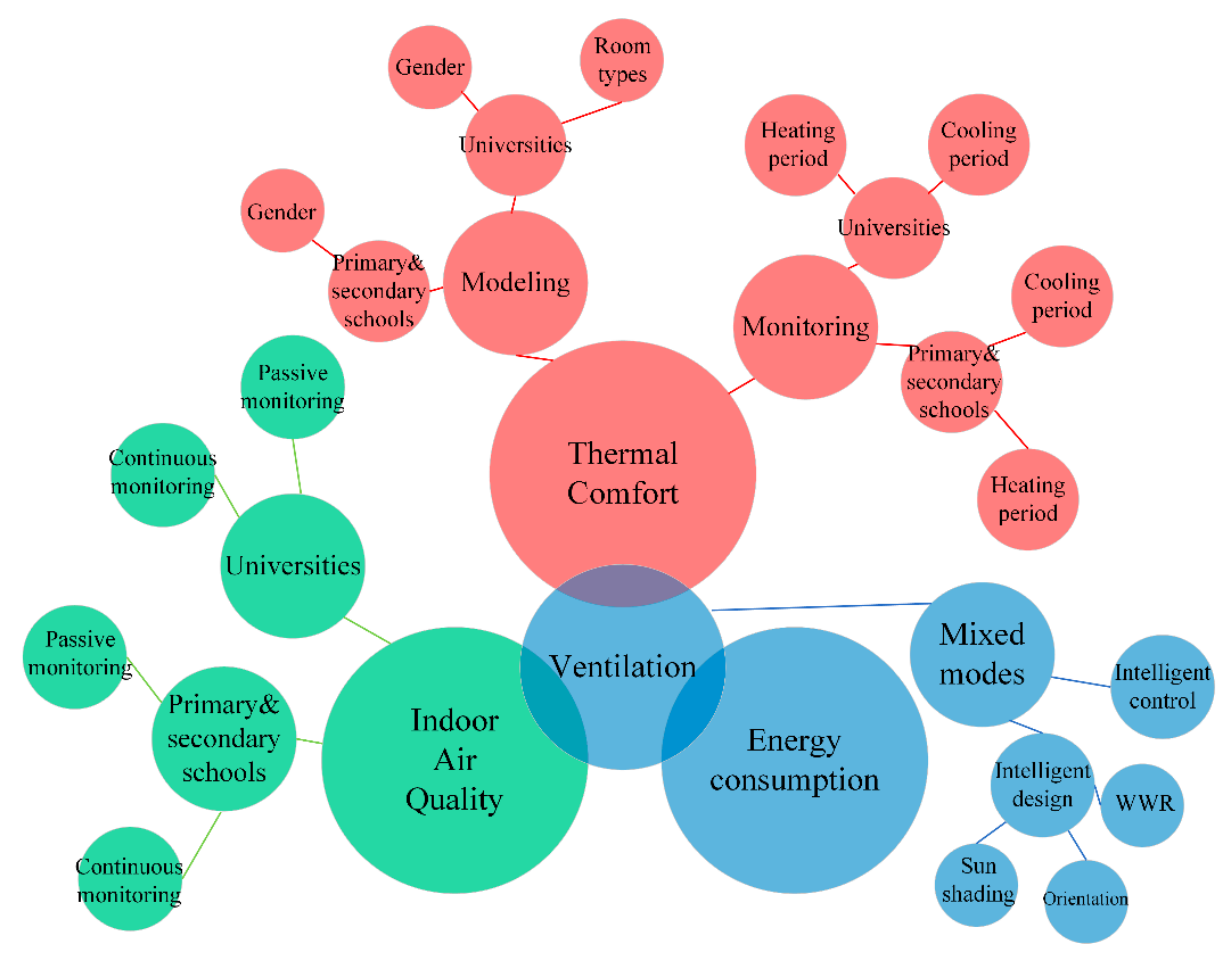

Figure 8. The scope of future directions among the thermal comfort, IAQ and ventilation energy.

\section{Conclusions and Limitations}

Thermal comfort and IAQ are the key factors that significantly affect students' perception of the indoor environment while interacting with building ventilation systems and corresponding energy consumption. Appropriate ventilation can guarantee thermal comfort and IAQ for building occupants, and current mechanical ventilation systems possesses a huge potential in energy reduction with the assistance of natural ventilation and optimal control strategies. This paper critically reviewed the interaction between thermal comfort, IAQ and ventilation energy consumption at different educational levels under different climates by conducting a detailed statistical summary and classification of the related publications.

Some important findings are concluded as follows:

(1) Occupants' thermal comfort conditions can affect the perception of IAQ to some extent by modulating the tolerance levels. Appropriate ventilation can adjust the thermal comfort and IAQ to an acceptable level with lower energy consumption. Most studies focus solely on thermal comfort, IAQ, or energy consumption, while few publications address multiple aspects simultaneously. The significant interaction between these three aspects should be covered in future research;

(2) Using natural ventilation alone usually cannot guarantee thermal comfort and IAQ in extreme winter and summer conditions, while continuous mechanical ventilation will cause huge energy consumption. Therefore, mixed-mode ventilation and its corresponding control strategies should be further explored. Given these situations, internet of things (IoT) based or artificial intelligence (AI) based control, as an effective method, can provide optimized solutions for mixed ventilation strategies to balance $\mathrm{NV}$ and $\mathrm{MV}$;

(3) Most research related to IAQ is limited to primary and secondary schools, and university buildings need to be paid more attention. It should be noticed that the distribution of indoor pollutants is varied in different rooms of the school, but there are no corresponding guidelines focused on this issue. There is also a lack of research on bacterial and fungal aerosol pollutants for a comprehensive assessment of IAQ in educational buildings; 
(4) Some preliminary studies indicated that there might be a relationship between socioeconomic vulnerability and school children's thermal sensation. However, the interactions between thermal comfort and students' socioeconomic backgrounds at different types of classrooms in varied climates are still unclear, limiting the improvement of indoor environmental quality. The current thermal comfort evaluation models fail to consider this influential factor;

(5) Considering the energy consumption, the passive designing of natural and mechanical ventilated classrooms benefits maintaining comfortable indoor environments. Optimizing WWRs for natural ventilation can help satisfy requirements in thermal comfort and IAQ while reducing energy consumption. Appropriate window orientation and sun shading can also limit the gains or losses of solar radiation, reduce the frequency of application of mechanical ventilation, and thus lower energy costs. However, there are not sufficient studies focused on the optimization among the WWR, window orientation and sun shading. Thus, more studies should be conducted to evaluate its impact on school buildings;

During the literature selection process, some studies focusing on the overall performance of the indoor environment quality are excluded from the review because IAQ and thermal comfort are not individually analyzed and their interactions with the energy consumption are hard to evaluate. However, the perception of thermal conditions and IAQ as a part of indoor environmental quality can be influenced by indoor acoustic and lighting environments. Therefore, a future review considering all four aspects may provide deeper insight and further useful suggestions for improving the overall indoor environment quality of educational buildings.

Author Contributions: Writing—original draft preparation, L.-R.J.; Supervision, Conceptualization, Writing-review \& editing, Funding acquisition, Project administration-J.H.; Supervision, Writingreview \& editing-X.C.; Investigation, Visualization, Resources: Q.-Y.L.; Investigation: C.-C.L. and Y.-H.F. All authors have read and agreed to the published version of the manuscript.

Funding: This work was financially supported by Research Grants Council of the Hong Kong Special Administrative Region, China (UGC/FDS16/P01/20) and Hong Kong Metropolitan University Research Grant (No. 2020/1.3).

Institutional Review Board Statement: Not applicable.

Informed Consent Statement: Not applicable.

Conflicts of Interest: The authors declare no conflict of interest.

\section{Nomenclature}

$\begin{array}{ll}\text { AHU } & \text { Air handling units } \\ \text { AI } & \text { Artificial intelligence } \\ \text { HVAC } & \text { Heating, ventilation and air conditioning } \\ \text { IAQ } & \text { Indoor air quality } \\ \text { IEQ } & \text { Indoor environmental quality } \\ \text { IoT } & \text { Internet of Things } \\ \text { MV } & \text { Mechanical ventilation } \\ \text { NV } & \text { Natural ventilation } \\ \text { WWR } & \text { Window-to-wall ratio } \\ \text { WHO } & \text { World health organization } \\ \text { N,P, S, and U } & \text { Nursery, Primary school, Secondary school, and University }\end{array}$

\section{References}

1. Heinzerling, D.; Schiavon, S.; Webster, T.; Arens, E. Indoor environmental quality assessment models: A literature review and a proposed weighting and classification scheme. Build. Environ. 2013, 70, 210-222. [CrossRef]

2. Landrigan, P.J.; Fuller, R.; Acosta, N.J.R.; Adeyi, O. The Lancet Commission on pollution and health. Lancet 2018, 391, 462-512. [CrossRef] 
3. Chithra, V.S.; Nagendra, S.M.S. Indoor air quality investigations in a naturally ventilated school building located close to an urban roadway in Chennai, India. Build. Environ. 2012, 54, 159-167. [CrossRef]

4. Korsavi, S.S.; Montazami, A.; Mumovic, D. The impact of indoor environment quality (IEQ) on school children's overall comfort in the UK; a regression approach. Build. Environ. 2020, 185, 107309. [CrossRef]

5. Kim, J.; Hong, T.; Jeong, J.; Lee, M.; Lee, M.; Jeong, K.; Koo, C.; Jeong, J. Establishment of an optimal occupant behavior considering the energy consumption and indoor environmental quality by region. Appl. Energy 2017, 204, 1431-1443. [CrossRef]

6. Kalimeri, K.K.; Saraga, D.E.; Lazaridis, V.D.; Legkas, N.A.; Missia, D.A.; Tolis, E.I.; Bartzis, J.G. Indoor air quality investigation of the school environment and estimated health risks: Two-season measurements in primary schools in Kozani, Greece. Atmos. Pollut. Res. 2016, 7, 1128-1142. [CrossRef]

7. Godoi, R.H.M.; Godoi, A.F.L.; Junior, S.J.G.; Paralovo, S.L.; Borillo, G.C.; Barbosa, C.G.G.; Arantes, M.G.; Charello, R.C.; Filho, N.A.R.; Grassi, M.T.; et al. Healthy environment-indoor air quality of Brazilian elementary schools nearby petrochemical industry. Sci. Total Environ. 2013, 463-464, 639-646. [CrossRef] [PubMed]

8. Fransson, N.; Västfjäll, D.; Skoog, J. In search of the comfortable indoor environment: A comparison of the utility of objective and subjective indicators of indoor comfort. Build. Environ. 2007, 42, 1886-1890. [CrossRef]

9. Almeida, R.M.S.F.; de Freitas, V.P. Indoor environmental quality of classrooms in Southern European climate. Energy Build. 2014, 81, 127-140. [CrossRef]

10. Pellerey, F.; Astolfi, A. Subjective and objective assessment of acoustical and overall environmental quality in secondary school classrooms. J. Acoust. Soc. Am. 2008, 123, 163-173.

11. Frontczak, M.; Schiavon, S.; Goins, J.; Arens, E.; Zhang, H.; Wargocki, P. Quantitative relationships between occupant satisfaction and satisfaction aspects of indoor environmental quality and building design. Indoor Air 2012, 22, 119-131. [CrossRef]

12. Sundell, J. On the history of indoor air quality and health. Indoor Air 2004, 14, 1-8. [CrossRef]

13. Zivelonghi, A.; Lai, M. Mitigating aerosol infection risk in school buildings: The role of natural ventilation, volume, occupancy and CO2 monitoring. Build. Environ. 2021, 204, 108139. [CrossRef]

14. Nicol, F.; Humphreys, M.; Roaf, S. Adaptive Thermal Comfort: Principles and Practice; Heriot-Watt University: Edinburgh, UK, 2012.

15. Nicol, F.; Humphreys, M. Derivation of the adaptive equations for thermal comfort in free-running buildings in European standard EN15251. Build. Environ. 2010, 45, 11-17. [CrossRef]

16. Mendell, M.J.; Heath, G.A. Do indoor pollutants and thermal conditions in schools influence student performance? A critical review of the literature. Indoor Air 2005, 15, 27-52. [CrossRef]

17. Ricciardi, P.; Buratti, C. Environmental quality of university classrooms: Subjective and objective evaluation of the thermal, acoustic, and lighting comfort conditions. Build. Environ. 2018, 127, 23-36. [CrossRef]

18. Barbhuiya, S.; Barbhuiya, S. Thermal comfort and energy consumption in a UK educational building. Build. Environ. 2013, 68, 1-11. [CrossRef]

19. Mors, S.T.; Hensen, J.L.M.; Loomans, M.G.L.C.; Boerstra, A.C. Adaptive thermal comfort in primary school classrooms: Creating and validating PMV-based comfort charts. Build. Environ. 2011, 46, 2454-2461. [CrossRef]

20. Kükrer, E.; Eskin, N. Effect of design and operational strategies on thermal comfort and productivity in a multipurpose school building. J. Build. Eng. 2021, 44, 1-14. [CrossRef]

21. Fanger, P.O. Thermal Comfort Analysis and Application in Environmential Engineering; Danish Technical Press: Copenhagen, Danmark, 1970.

22. Deng, J.; Wei, Q.; Liang, M.; He, S.; Zhang, H. Field test on energy performance of medium-depth geothermal heat pump systems (MD-GHPs). Energy Build. 2019, 184, 289-299. [CrossRef]

23. Lee, S.C.; Chang, M. Indoor and outdoor air quality investigation at schools in Hong Kong. Chemosphere 2000, 41, 109-113. [CrossRef]

24. Yang, J.; Nam, I.; Yun, H.; Kim, J.; Oh, H.-J.; Lee, D.; Jeon, S.-M.; Yoo, S.-H.; Sohn, J.-R. Characteristics of indoor air quality at urban elementary schools in Seoul, Korea: Assessment of effect of surrounding environments. Atmos. Pollut. Res. 2015, 6, 1113-1122. [CrossRef]

25. Norbäck, D.; Torgén, M.; Edling, C. Volatile organic compounds, respirable dust, and personal factors related to prevalence and incidence of sick building syndrome in primary schools. Occup. Environ. Med. 1990, 47, 733-741. [CrossRef]

26. Shendell, D.G.; Prill, R.; Fisk, W.J.; Apte, M.G.; Blake, D.; Faulkner, D. Associations between classroom $\mathrm{CO}_{2}$ concentrations and student attendance in Washington and Idaho. Indoor Air 2004, 14, 333-341. [CrossRef] [PubMed]

27. Sørensen, M.; Autrup, H.; Møller, P.; Hertel, O.; Jensen, S.S.; Vinzents, P.; Knudsen, L.E.; Loft, S. Linking exposure to environmental pollutants with biological effects. Mutat. Res./Rev. Mutat. Res. 2003, 544, 255-271. [CrossRef] [PubMed]

28. Oh, H.-J.; Nam, I.-S.; Yun, H.; Kim, J.; Yang, J.; Sohn, J.-R. Characterization of indoor air quality and efficiency of air purifier in childcare centers, Korea. Build. Environ. 2014, 82, 203-214. [CrossRef]

29. Zhong, K.; Yang, F.; Kang, Y. Indoor and outdoor relationships of co concentrations in natural ventilating rooms in summer, Shanghai. Build. Environ. 2013, 62, 69-76. [CrossRef]

30. Schembari, A.; Triguero-Mas, M.; Nazelle, A.; Dadvand, P.; Vrijheid, M.; Martinez, M.C.D.; Querol, F.F.X.; Basagaña, X.; Eeftens, M.; Meliefste, K.; et al. Personal, indoor and outdoor air pollution levels among pregnant women. Atmos. Environ. 2013, 64, 287-295. [CrossRef] 
31. Rivas, I.; Viana, M.; Moreno, T.; Pandolfi, M.; Amato, F.; Reche, C.; Bouso, L.; Àlvarez-Pedrerol, M.; Alastuey, A.; Sunyer, J.; et al. Child exposure to indoor and outdoor air pollutants in schools in Barcelona, Spain. Environ. Int. 2014, 69, 200-212. [CrossRef] [PubMed]

32. Weichenthal, S.; Dufresne, A.; Joseph, C.R.L. Characterizing and predicting ultrafine particle counts in Canadian classrooms during the winter months: Model development and evaluation. Environ. Res. 2008, 106, 349-360. [CrossRef]

33. Madureira, J.; Paciência, I.; Pereira, C.; Teixeira, J.P.; Fernandes, E.D.O. Indoor air quality in Portuguese schools: Levels and sources of pollutants. Indoor Air 2016, 26, 526-537. [CrossRef] [PubMed]

34. Fromme, H.; Twardella, D.; Dietrich, S.; Heitmann, D.; Schierl, R.; Liebl, B.; Rüden, H. Particulate matter in the indoor air of classrooms-exploratory results from Munich and surrounding area. Atmos. Environ. 2007, 41, 854-866. [CrossRef]

35. Becerra, J.A.; Lizana, J.; Gil, M.; Barrios-Padura, A.; Blondeau, P.; Chacartegui, R. Identification of potential indoor air pollutants in schools. J. Clean. Prod. 2020, 242, 118420. [CrossRef]

36. Bennett, J.; Davy, P.; Trompetter, B.; Wang, Y.; Pierse, N.; Boulic, M.; Phipps, R.; Howden-Chapman, P. Sources of indoor air pollution at a New Zealand urban primary school; a case study. Atmos. Pollut. Res. 2019, 10, 435-444. [CrossRef]

37. Branco, P.T.B.S.; Alvim-Ferraz, M.C.M.; Martins, F.G.; Sousa, S.I.V. Quantifying indoor air quality determinants in urban and rural nursery and primary schools. Environ. Res. 2019, 176, 108534. [CrossRef] [PubMed]

38. Li, Y.; Leung, G.M.; Tang, J.W.; Yang, X.; Chao, C.Y.H.; Lin, J.Z.; Lu, J.W.; Nielsen, P.V.; Niu, J.; Qian, H.; et al. Role of ventilation in airborne transmission of infectious agents in the built environment-A multidisciplinary systematic review. Indoor Air 2007, 17, 2-18. [CrossRef] [PubMed]

39. Ma, N.; Aviv, D.; Guo, H.; Braham, W.W. Measuring the right factors: A review of variables and models for thermal comfort and indoor air quality. Renew. Sustain. Energy Rev. 2021, 135, 110436. [CrossRef]

40. Vassella, C.C.; Koch, J.; Henzi, A.; Jordan, A.; Waeber, R.; Iannaccone, R.; Charrière, R. From spontaneous to strategic natural window ventilation: Improving indoor air quality in Swiss schools. Int. J. Hyg. Environ. Health 2021, 234, 113746. [CrossRef]

41. Khan, N.; Su, Y.; Riffat, S.B. A review on wind driven ventilation techniques. Energy Build. 2008, 40, 1586-1604. [CrossRef]

42. Yuan, F.; Yao, R.; Sadrizadeh, S.; Li, B. Thermal comfort in hospital buildings-A literature review. J. Build. Eng. 2022, 45, 103463. [CrossRef]

43. Sharma, A.; Kumar, A.; Kulkarni, K.S. Thermal comfort studies for the naturally ventilated built environments in Indian subcontinent: A review. J. Build. Eng. 2021, 44, 103242. [CrossRef]

44. Yüksel, A.; Arıcı, M.; Krajčík, M. A review on thermal comfort, indoor air quality and energy consumption in temples. J. Build. Eng. 2021, 25, 102013. [CrossRef]

45. Wang, Y.; Kuckelkorn, J.; Zhao, F.-Y.; Liu, D.; Kirschbaum, A.; Zhang, J.-L. Evaluation on classroom thermal comfort and energy performance of passive school building by optimizing HVAC control systems. Build. Environ. 2015, 89, 86-106. [CrossRef]

46. Zomorodian, Z.S.; Tahsildoost, M.; Hafezi, M. Thermal comfort in educational buildings: A review article. Renew. Sustain. Energy Rev. 2016, 59, 895-906. [CrossRef]

47. De Dear, R.J.; Akimoto, T.; Arens, E.A.; Brager, G.; Candido, C.; Cheong, K.W.D.; Li, B.; Nishihara, N.; Sekhar, S.C.; Tanabe, S.; et al. Progress in thermal comfort research over the last twenty years. Indoor Air 2013, 23, 442-461. [CrossRef] [PubMed]

48. Rupp, R.F.; Vásquezb, N.G.; Lamberts, R. A review of human thermal comfort in the built environment. Energy Build. 2015, 105, 178-205. [CrossRef]

49. Yau, Y.H.; Chew, B.T. A review on predicted mean vote and adaptive thermal comfort models. J. Build. Serv. Eng. Res. Technol. 2014, 35, 23-35. [CrossRef]

50. Aparicio-Ruiz, P.; Barbadilla-Martín, E.; Guadix, J.; Muñuzuri, J. A field study on adaptive thermal comfort in Spanish primary classrooms during summer season. Build. Environ. 2021, 203, 1-14. [CrossRef]

51. Ali, H.H.; Al-Hashlamun, R. Assessment of indoor thermal environment in different prototypical school buildings in Jordan. Alex. Eng. J. 2019, 58, 699-711. [CrossRef]

52. Singh, M.K.; Kumar, S.; Ooka, R.; Rijal, H.B.; Gupta, G.; Kumar, A. Status of thermal comfort in naturally ventilated classrooms during the summer season in the composite climate of India. Build. Environ. 2018, 128, 287-304. [CrossRef]

53. Yao, R.; Li, B.; Liu, J. A theoretical adaptive model of thermal comfort adaptive Predicted Mean Vote (aPMV). Build. Environ. 2009, 44, 2089-2096. [CrossRef]

54. Havenith, G.; Holmer, I.; Parsons, K. Personal factors in thermal comfort assessment; clothing properties and metabolic heat production. Energy Build. 2002, 34, 581-591. [CrossRef]

55. Rupp, R.F.; Parkinson, T.; Kim, J.; Toftum, J.; Dear, R. The impact of occupant's thermal sensitivity on adaptive thermal comfort model. Build. Environ. 2021, 108517. [CrossRef]

56. Brager, G.S.; Dear, R.J.D. Thermal adaptation in the built environment: A literature review. Energy Build. 1998, $27,83-96$. [CrossRef]

57. Baker, N.; Standeven, M. Thermal comfort for free-running buildings. Energy Build. 1996, 23, 175-182. [CrossRef]

58. Aghniaey, S.; Lawrence, T.M.; Sharpton, T.N.; Douglass, S.P.; Oliver, T.; Sutter, M. Thermal comfort evaluation in campus classrooms during room temperature adjustment corresponding to demand response. Build. Environ. 2019, 148, 488-497. [CrossRef]

59. Yang, B.; Olofsson, T.; Wang, F.; Lu, W. Thermal comfort in primary school classrooms: A case study under subarctic climate area of Sweden. Build. Environ. 2018, 135, 237-245. [CrossRef] 
60. Cheng, F.; Wu, Y.; Gao, S.; Liao, C.; Cheng, Y. Experimental study of thermal comfort in a field environment chamber with stratum ventilation system in winter. Build. Environ. 2022, 207, 108445. [CrossRef]

61. Gil-Baez, M.; Barrios-Padura, A.; Molina-Huelva, M.; Chacartegui, R. Natural ventilation systems in 21st-century for near zero energy school buildings. Energy 2017, 137, 1186-1200. [CrossRef]

62. Kim, J.; de Dear, R. Thermal comfort expectations and adaptive behavioural characteristics of primary and secondary school students. Build. Environ. 2018, 127, 13-22. [CrossRef]

63. Hamzah, B.; Gou, Z.; Mulyadi, R.; Amin, S. Thermal comfort analyses of secondary school students in the tropics. Buildings 2018, 8, 56. [CrossRef]

64. Haddad, S.; Osmond, P.; King, S. Application of adaptive thermal comfort methods for Iranian schoolchildren. Build. Res. Inf. 2019, 47, 173-189. [CrossRef]

65. Montazami, A.; Gaterell, M.; Nicol, F.; Lumley, M.; Thoua, C. Impact of social background and behaviour on children's thermal comfort. Build. Environ. 2017, 122, 422-434. [CrossRef]

66. Teli, D.; Jentsch, M.F.; James, P.A.B. The role of a building's thermal properties on pupils' thermal comfort in junior school classrooms as determined in field studies. Build. Environ. 2014, 82, 640-654. [CrossRef]

67. Teli, D.; Jentsch, M.F.; James, P.A.B. Naturally ventilated classrooms: An assessment of existing comfort models for predicting the thermal sensation and preference of primary school children. Energy Build. 2012, 53, 166-182. [CrossRef]

68. Singh, M.K.; Ooka, R.; Rijal, H.B.; Kumar, S.; Kumar, A.; Mahapatra, S. Progress in thermal comfort studies in classrooms over last 50 years and way forward. Energy Build. 2019, 188-189, 149-174. [CrossRef]

69. Corgnati, S.P.; Filippi, M.; Viazzo, S. Perception of the thermal environment in high school and university classrooms: Subjective preferences and thermal comfort. Build. Environ. 2007, 42, 951-959. [CrossRef]

70. Giuli, V.D.; Pos, O.D.; Carli, M.D. Indoor environmental quality and pupil perception in Italian primary schools. Build. Environ. 2012, 56, 335-345. [CrossRef]

71. Korsavi, S.S.; Montazami, A. Children's thermal comfort and adaptive behaviours; UK primary schools during non-heating and heating seasons. Energy Build. 2020, 214, 1-19. [CrossRef]

72. Trebilcock, M.; Soto-Muñoz, J.; Yañez, M.; Martin, R.F.-S. The right to comfort: A field study on adaptive thermal comfort in free-running primary schools in Chile. Build. Environ. 2017, 114, 455-469. [CrossRef]

73. Trebilcock, M.; Piderit, B.; Soto, J.; Figueroa, R. A parametric analysis of simple passive strategies for improving thermal performance of school classrooms in Chile. Archit. Sci. Rev. 2016, 59, 385-399. [CrossRef]

74. Buratti, C.; Palladino, D.; Ricciardi, P. Application of a new 13-value thermal comfort scale to moderate environments. Appl. Energy 2016, 180, 859-866. [CrossRef]

75. Bakó-Biró, Z.; Clements-Croome, D.J.; Kochhar, N.; Awbi, H.B. Ventilation rates in schools and pupils' performance. Build. Environ. 2007, 48, 1434-1440. [CrossRef]

76. Wargocki, P.; Wyon, D.P. The effects of moderately raised classroom temperatures and classroom ventilation rate on the performance of schoolwork by children. HVACR Res. 2007, 13, 193-220. [CrossRef]

77. Ukawa, S.; Araki, A.; Kanazawa, A.; Yuasa, M. The relationship between atopic dermatitis and indoor environmental factors: A cross-sectional study among Japanese elementary school children. Int. Arch. Occup. Environ. Health 2013, 86, 77-87. [CrossRef] [PubMed]

78. Al-Rashidi, K.; Loveday, D.; Al-Mutawa, N. Impact of ventilation modes on carbon dioxide concentration levels in Kuwait classrooms. Energy Build 2012, 47, 540-549. [CrossRef]

79. Mumovic, D.; Palmer, J.; Davies, M.; Orme, M.; Ridley, I.; Oreszczyn, T.; Judd, C.; Critchlow, R.; Medina, H.A.; Pilmoor, G.; et al. Winter indoor air quality, thermal comfort and acoustic performance of newly built secondary schools in England. Build. Environ. 2009, 44, 1466-1477. [CrossRef]

80. Conceição, E.Z.E.; Lúcio, M.M.J.R. Thermal study of school buildings in winter conditions. Build. Environ. 2008, 43, 782-792. [CrossRef]

81. Tian, Z.; Zhang, X.; Jin, X.; Zhou, X.; Si, B.; Shi, X. Towards adoption of building energy simulation and optimization for passive building design: A survey and a review. Energy Build. 2018, 158, 1306-1316. [CrossRef]

82. Wang, D.; Jiang, J.; Liu, Y.; Wang, Y.; Xu, Y.; Liu, J. Student responses to classroom thermal environments in rural primary and secondary schools in winter. Build. Environ. 2017, 115, 104-117. [CrossRef]

83. Liang, H.-H.; Lin, T.-P.; Hwang, R.-L. Linking occupants' thermal perception and building thermal performance in naturally ventilated school buildings. Appl. Energy 2012, 94, 355-363. [CrossRef]

84. Dias Pereira, L.; Raimondo, D.; Corgnati, S.P.; Gameiro da Silva, M. Assessment of indoor air quality and thermal comfort in Portuguese secondary classrooms: Methodology and results. Build. Environ. 2014, 81, 69-80. [CrossRef]

85. Katafygiotou, M.C.; Serghides, D.K. Thermal comfort of a typical secondary school building in Cyprus. Sustain. Cities Soc. 2014, 13, 303-312. [CrossRef]

86. Jowkar, M.; Rijal, H.B.; Brusey, J.; Montazami, A.; Carlucci, S.; Lansdown, T.C. Comfort temperature and preferred adaptive behaviour in various classroom types in the UK higher learning environments. Energy Build. 2020, 211, 1-15. [CrossRef]

87. Mishra, A.; Ramgopal, M. Thermal comfort field study in undergraduate laboratories-An analysis of occupant perceptions. Build. Environ. 2014, 76, 62-72. [CrossRef] 
88. Yao, R.; Liu, J.; Li, B. Occupants' adaptive responses and perception of thermal environment in naturally conditioned university classrooms. Appl. Energy 2010, 87, 1015-1022. [CrossRef]

89. Kumar, S.; Singh, M.K.; Mathu, A.; Mathur, J.; Mathur, S. Evaluation of comfort preferences and insights into behavioural adaptation of students in naturally ventilated classrooms in a tropical country, India. Build. Environ. 2018, 143, 532-547. [CrossRef]

90. Mishra, A.K.; Ramgopal, M. A thermal comfort field study of naturally ventilated classrooms in Kharagpur, India. Build. Environ. 2015, 92, 396-406. [CrossRef]

91. Nico, M.A.; Liuzzi, S.; Stefanizzi, P. Evaluation of thermal comfort in university classrooms through objective approach and subjective preference analysis. Appl. Ergon. 2015, 48, 111-120. [CrossRef]

92. Zhang, G.; Zheng, C.; Yang, W.; Zhang, Q.; Moschandreasa, D.J. Thermal comfort investigation of naturally ventilated classrooms in a subtropical region. Indoor Built Environ. 2007, 16, 148-158. [CrossRef]

93. Krüger, E.L.; Zannin, P.H.T. Acoustic, thermal and luminous comfort in classrooms. Build. Environ. 2004, 39, 1055-1063. [CrossRef]

94. Corgnati, S.P.; Ansaldi, R.; Filippi, M. Thermal comfort in Italian classrooms under free running conditions during mid seasons: Assessment through objective and subjective approaches. Build. Environ. 2009, 44, 785-792. [CrossRef]

95. Baruah, P.; Singh, M.K.; Mahapatra, S. Thermal comfort in naturally ventilated classrooms. In Proceedings of the 30th International PLEA Conference, Ahmedabad, India, 16-18 December 2014.

96. Costa, M.L.; Freire, M.R.; Kiperstok, A. Strategies for thermal comfort in university buildings-The case of the faculty of architecture at the Federal University of Bahia, Brazil. J. Environ. Manag. 2019, 239, 114-123. [CrossRef]

97. Hwang, R.; Lin, T.; Kuo, N. Field experiments on thermal comfort in campus classrooms in Taiwan. Energy Build. 2006, 38, 53-62. [CrossRef]

98. Jing, S.; Lei, Y.; Wang, H.; Song, C.; Yan, X. Thermal comfort and energy-saving potential in university classrooms during the heating season. Energy Build. 2019, 202, 1-11. [CrossRef]

99. Mishra, A.K.; Derks, M.T.H.; Kooi, L.; Loomans, M.G.L.C.; Kort, H.S.M. Analysing thermal comfort perception of students through the class hour, during heating season, in a university classroom. Build. Environ. 2017, 125, 464-474. [CrossRef]

100. Fanga, Z.; Zhang, S.; Cheng, Y.Y.; Fong, A.M.L.; Oladokun, M.O.; Lind, Z.; Wu, H. Field study on adaptive thermal comfort in typical air conditioned classrooms. Build. Environ. 2018, 133, 73-82. [CrossRef]

101. Wang, Z.; Ning, H.; Zhang, X.; Ji, Y. Human Thermal Adaptation in University Classrooms and Dormitories in Chinese Severe Cold Area in Winter. Procedia Eng. 2016, 146, 24-31. [CrossRef]

102. Fong, M.L.; Hanby, V.; Greenough, R.; Lin, Z.; Cheng, Y. Acceptance of thermal conditions and energy use of three ventilation strategies with six exhaust configurations for the classroom. Build. Environ. 2015, 94, 606-619. [CrossRef]

103. Serghides, D.K.; Chatzinikola, C.K.; Katafygiotou, M.C. Comparative studies of the occupants' behaviour in a university building during winter and summer time. Int. J. Sustain. Energy 2015, 34, 528-551. [CrossRef]

104. Davidsson, H.; Bernardo, R.; Hellstrom, B. Theoretical and Experimental Investigation of a Heat Exchanger Suitable for a Hybrid Ventilation System. Buildings 2013, 3, 18-38. [CrossRef]

105. Turanjanin, V.; Vučićević, B.; Jovanović, M.; Mirkov, N.; Lazović, I. Indoor $\mathrm{CO}_{2}$ measurements in Serbian schools and ventilation rate calculation. Energy 2014, 77, 290-296. [CrossRef]

106. Stabile, L.; Dell'Isola, M.; Russi, A.; Massimo, A.; Buonanno, G. The effect of natural ventilation strategy on indoor air quality in schools. Sci. Total Environ. 2017, 595, 894-902. [CrossRef] [PubMed]

107. ESFA. Guidance on Ventilation, Thermal Comfort and Indoor Air Quality in Schools. In Building Bulletin 101. Draft for Public Consultation; Department for Education: London, UK, 2005; ISBN 011-2711642.

108. Mainka, A.; Bragoszewska, E.; Kozielska, B.; Pastuszka, J.S.; Zajusz-Zubek, E. Indoor air quality in urban nursery schools in Gliwice, Poland: Analysis of the case study. Atmos. Pollut. Res. 2015, 6, 1098-1104. [CrossRef]

109. Heebøll, A.; Wargocki, P.; Toftum, J. Window and door opening behavior, carbon dioxide concentration, temperature, and energy use during the heating season in classrooms with different ventilation retrofits-ASHRAE RP1624. Sci. Technol. Built Environ. 2018, 24, 626-637. [CrossRef]

110. Cai, C.; Sun, Z.; Weschler, L.B.; Li, T.; Xu, W.; Zhang, Y. Indoor air quality in schools in Beijing: Field tests, problems and recommendations. Build. Environ. 2021, 205, 108179. [CrossRef]

111. Heracleous, C.; Michael, A. Thermal comfort models and perception of users in free-running school buildings of EastMediterranean region. Energy Build. 2020, 215, 1-17. [CrossRef]

112. Heracleous, C.; Michael, A. Experimental assessment of the impact of natural ventilation on indoor air quality and thermal comfort conditions of educational buildings in the Eastern Mediterranean region during the heating period. J. Build. Eng. 2019, 26, 1-15. [CrossRef]

113. WHO. Air Quality Guidelines for Particulate Matter, Ozone, Nitrogen Dioxide and Sulfur Dioxide; World Health Organization: Geneva, Switzerland, 2005.

114. Madureira, J.; Paciência, I.; Rufo, J.; Ramos, E.; Barros, H.; Teixeira, J.P.; de Oliveira Fernandes, E. Indoor air quality in schools and its relationship with children's respiratory symptoms. Atmos. Environ. 2015, 118, 145-156. [CrossRef]

115. Poupard, O.; Blondeau, P.; Iordache, V.; Allard, F. Statistical analysis of parameters influencing the relationship between outdoor and indoor air quality in schools. Atmos. Environ. 2005, 39, 2071-2080. [CrossRef] 
116. Chan, L.Y.; Kwok, W.S.; Chan, C.Y. Human exposure to respirable suspended particulate and airborne lead in different roadside microenvironments. Chemosphere 2000, 41, 3-9. [CrossRef]

117. Yang, D.; Mak, C.M. Effects of acoustical descriptors on speech intelligibility in Hong Kong classrooms. Appl. Acoust. 2021, 171, 107678. [CrossRef]

118. Leppänen, M.; Peräniemi, S.; Koponen, H.; Sippul, O.; Pasanen, P. The effect of the shoeless course on particle concentrations and dust composition in schools. Sci. Total Environ. 2020, 710, 136272. [CrossRef]

119. Zhou, L.; Chen, J.; Song, Z.; Ge, Z. Semi-supervised PLVR models for process monitoring with unequal sample sizes of process variables and quality variables. J. Process. Control 2015, 26, 1-16. [CrossRef]

120. Hutter, H.P.; Moshammer, H.; Wallner, P.; Tappler, P.; Kundi, M. Volatile organic compounds: Guidelines from the Austrian working group on indoor air. Proc. Indoor Air 2005, 2005, 3519-3522.

121. Hernandez, G.; Wallis, S.L.; Graves, L.; Narain, S.; Birchmore, R.; AnnBerry, T. The effect of ventilation on volatile organic compounds produced by new furnishings in residential buildings. Atmos. Environ. X 2020, 6, 100069.

122. Hu, K.; Chen, Q. Ventilation optimization for reduction of indoor semi-volatile organic compound concentration based on the variational principle. Build. Environ. 2015, 94, 676-682. [CrossRef]

123. Wang, J.; Smedje, G.; Nordquist, T.; Norbäck, D. Personal and demographic factors and change of subjective indoor air quality reported by school children in relation to exposure at Swedish schools: A 2-year longitudinal study. Sci. Total. Environ. 2015, 508, 288-296. [CrossRef]

124. Bluyssen, P.M. The Indoor Environment Handbook: How to Make Buildings Healthy and Comfortable. Routledge: London, UK, 2009.

125. Majd, E.; McCormack, M.; Davis, M.; Curriero, F.; Berman, J.; Connolly, F.; Leaf, P.; Rule, A.; Green, T.; Clemons-Erby, D.; et al. Indoor air quality in inner-city schools and its associations with building characteristics and environmental factors. Environ. Res. 2019, 170, 83-91. [CrossRef] [PubMed]

126. Al-Hemoud, A.; Al-Awadi, L.; Al-Rashidi, M.; Rahman, K.A.; Al-Khayat, A.; Behbehani, W. Comparison of indoor air quality in schools: Urban vs. Industrial 'oil \& gas' zones in Kuwait. Build. Environ. 2017, 122, 50-60. [CrossRef]

127. Haddad, S.; Synnefa, A.; Ángel Padilla Marcos, M.; Paolini, R.; Delrue, S.; Prasad, D.; Santamouris, M. On the potential of demand-controlled ventilation system to enhance indoor air quality and thermal condition in Australian school classrooms. Energy Build. 2021, 238, 110838. [CrossRef]

128. Jovanović, M.; Vučićević, B.; Turanjanin, V.; Živković, M.; Spasojević, V. Investigation of indoor and outdoor air quality of the classrooms at a school in Serbia. Energy 2014, 77, 42-48. [CrossRef]

129. Mohamed, S.; Rodrigues, L.; Omer, S.; Calautit, J. Overheating and Indoor Air Quality in Primary Schools in the UK. Energy Build. 2021, 250, 111291. [CrossRef]

130. Yang, W.; Sohn, J.; Kim, J.; Son, B.; Park, J. Indoor air quality investigation according to age of the school buildings in Korea. J. Environ. Manag. 2009, 90, 348-354. [CrossRef]

131. Theodosiou, T.G.; Ordoumpozanis, K.T. Energy, comfort and indoor air quality in nursery and elementary school buildings in the cold climatic zone of Greece. Energy Build. 2008, 40, 2207-2214. [CrossRef]

132. Alves, C.; Vicente, E.; Evtyugina, M.; Vicente, A.M. Indoor and outdoor air quality: A university cafeteria as a case study. Atmos. Pollut. Res. 2020, 11, 531-544. [CrossRef]

133. Fan, G.; Xie, J.; Liu, J. Indoor air quality in a naturally ventilated research student office in chinese university during the heating period. Procedia Eng. 2017, 205, 1272-1278. [CrossRef]

134. Abd, A.; Sumiyoshi, D.; Akashi, Y. Low cost humidity controlled air-conditioning system for building energy savings in tropical climate. J. Build. Eng. 2017, 11, 9-16.

135. Yang, J.; Wang, Y.; Bing Xue, Y.L.; Xiao, X.; Xia, J.C.; He, B. Contribution of urban ventilation to the thermal environment and urban energy demand: Different climate background perspectives. Sci. Total Environ. 2021, 795, 148791. [CrossRef]

136. Stabile, L.; Massimo, A.; Canale, L.; Russi, A.; Andrade, A.; Dell'lsola, M. The Effect of Ventilation Strategies on Indoor Air Quality and Energy Consumptions in Classrooms. Buildings 2019, 9, 110. [CrossRef]

137. Gustafsson, M.; Dermentzis, G.; AreMyhren, J.; Bales, C.; Ochs, F.; Holmberg, S.; Feistb, W. Energy performance comparison of three innovative HVAC systems for renovation through dynamic simulation. Energy Build. 2014, 82, 2-9. [CrossRef]

138. Stabile, L.; Buonanno, G.; Frattolillo, A.; Dell'Isola, M. The effect of the ventilation retrofit in a school on $\mathrm{CO}_{2}$, airborne particles, and energy consumptions. Build. Environ. 2019, 156, 1-11. [CrossRef]

139. Haghshenaskashani, S.; Sajadi, B. Evaluation of thermal comfort, IAQ and energy consumption in an impinging jet ventilation (IJV) system with/without ceiling exhaust. J. Build. Eng. 2018, 18, 142-153. [CrossRef]

140. Jagadeesh, L.R.; Mahesh, L. Experimental and numerical analysis of temperature and air flow in the classroom using CFD. Mater. Today Proc. 2021, 45, 385-388. [CrossRef]

141. Wang, Y.; Zhao, F.; Kuckelkorn, J.; Li, X.; Wang, H. Indoor air environment and night cooling energy efficiency of a southern German passive public school building operated the heat recovery air conditioning unit. Energy Build. 2014, 81, 9-17. [CrossRef]

142. Prabhakar, M.; Saffari, M.; Gracia, A.d.; Cabeza, L.F. Improving the energy efficiency of passive PCM system using controlled natural ventilation. Energy Build. 2020, 228, 110483. [CrossRef]

143. Gainza-Barrencua, J.; Odriozola-Maritorena, M.; Minguillon, R.H.; Gomez-Arriaran, I. Energy savings using sunspaces to preheat ventilation intake air: Experimental and simulation study. J. Build. Eng. 2021, 40, 102343. [CrossRef] 
144. Che, W.W.; Tso, C.Y.; Sun, L.; Ip, D.Y.K.; Lee, H.; Chao, C.Y.H.; Lau, A.K.H. Energy consumption, indoor thermal comfort and air quality in a commercial office with retrofitted heat, ventilation and air conditioning (HVAC) system. Energy Build. 2019, 201, 202-215. [CrossRef]

145. Schibuola, L.; Tambani, C. High energy efficiency ventilation to limit COVID-19 contagion in school environments. Energy Build. 2021, 240, 110882. [CrossRef]

146. Wang, Y.; Zhao, F.-Y.; Kuckelkorn, J.; Spliethoff, H.; Rank, E. School building energy performance and classroom air environment implemented with the heat recovery heat pump and displacement ventilation system. Appl. Energy 2014, 114, 58-68. [CrossRef]

147. Ji, Y.; Lomas, K.J.; Cook, M.J. Hybrid ventilation for low energy building design in south China. Build. Environ. 2009, 44, 2245-2255. [CrossRef]

148. Huertas, D.B.; Bellido, C.R.; Fargallo, A.P.; Pulido-Arcas, J.A. Energy saving potential in current and future world built environments based on the adaptive comfort approach. J. Clean. Prod. 2020, 249, 119306. [CrossRef]

149. Zhao, L.; Liu, J.; Ren, J. Impact of various ventilation modes on IAQ and energy consumption in Chinese dwellings: First long-term monitoring study in Tianjin, China. Build. Environ. 2018, 143, 99-106. [CrossRef]

150. Ma'bdeh, S.N.; Al-Zghoul, A.; Alradaideh, T.; Bataineh, A.; Ahmad, S. Simulation study for natural ventilation retrofitting techniques in educational classrooms-A case study. Heliyon 2020, 6, 1-19. [CrossRef] [PubMed]

151. De Abreu-Harbich, L.V.; Chaves, V.L.; Brandstetter, M.C.G. Evaluation of strategies that improve the thermal comfort and energy saving of a classroom of an institutional building in a tropical climate. Build. Environ. 2018, 135, 257-268. [CrossRef]

152. Bienvenido-Huertas, D.; Sánchez-García, D.; Rubio-Bellido, C. Analysing natural ventilation to reduce the cooling energy consumption and the fuel poverty of social dwellings in coastal zones. Appl. Energy 2020, 279, 115845. [CrossRef] [PubMed]

153. Sung, W.; Hsiao, S. The application of thermal comfort control based on Smart House System of IoT. Measurement 2020, $149,106997$. [CrossRef]

154. Yu, K.; Chen, Y.; Jaimes, E.; Wu, W.; Liao, K.; Liao, J.; Lu, K.; Sheu, W.; Wang, C. Optimization of thermal comfort, indoor quality, and energy-saving in campus classroom through deep Q learning. Case Stud. Therm. Eng. 2021, 24, 100842. [CrossRef]

155. Ashrafian, T.; Moazzen, N. The impact of glazing ratio and window configuration on occupants' comfortand energy demand: The case study of a school building in Eskisehir, Turke. Sustain. Cities Soc. 2019, 47, 101483. [CrossRef]

156. Phillips, R.; Troup, L.; Fannon, D.; Eckelman, M.J. Triple bottom line sustainability assessment of window-to-wall ratio in US office buildings. Build. Environ. 2020, 182, 107057. [CrossRef]

157. Lakhdari, K.; Sriti, L.; Painter, B. Parametric optimization of daylight, thermal and energy performance of middle school classrooms, case of hot and dry regions. Build. Environ. 2021, 204, 108173. [CrossRef]

158. Schünemann, C.; Schiela, D.; Ortlepp, R. How window ventilation behaviour affects the heat resilience in multi-residential buildings. Build. Environ. 2021, 202, 107987. [CrossRef]

159. Chi, F.; Wang, Y.; Wang, R.; Li, G.; Peng, C. An investigation of optimal window-to-wall ratio based on changes in building orientations for traditional dwellings. Sol. Energy 2020, 195, 64-81. [CrossRef]

160. Troup, L.; Phillips, R.; Eckelman, M.J.; Fannon, D. Effect of window-to-wall ratio on measured energy consumption in US office buildings. Energy Build. 2019, 23, 109434. [CrossRef] 